


\section{Online folyóirat}

Szerkesztette: VÁGÁNY Judit Bernadett, PhD - FENYVESI Éva, PhD

Borító: FLOW PR

Kiadja: Budapesti Gazdasági Egyetem, Kereskedelmi, Vendéglátóipari és Idegenforgalmi Kar, Közgazdasági és Üzleti Tudományok Tanszék

Felelős kiadó: FENYVESI Éva, PhD

a Közgazdasági és Üzleti Tudományok Tanszék vezetője

ISSN 2630-886X

2019. 


\title{
A MAGYAR TOP CÉGEK A TURIZMUSBAN, AVAGY EGY SIKERRE ÉHES ÁGAZAT PÉNZÜGYI DIAGNÓZISA
}

\author{
HUNGARIAN TOP COMPANIES IN TOURISM, OR \\ FINANCIAL DIAGNOSIS FOR A SUCCESFUL SECTOR
}

KATITS Etelka - SZALKA Éva - NAGY Franciska - KÖNCZÖL Tamás

Kulcsszavak: turizmus eset-és adatbázis elemzés, pénzügyi diagnózis, növekedési lehetöségek, nem szisatematikus kockáąat

Keywords: tourism case and database analysis, financial diagnosis, growth opportunities, nonsystematic risk

JEL kód: C10, G30, M21, Z3 


\section{ÖSSZEFOGLALÓ}

Azt a hazai gazdasági szeletort vizsgáljuk, amely napjainkban már 1000 milliárd forint feletti forgalmat teljesit. A pénzügyi átvilágitás tartalmi jegyeire fókuszálunk. Az integrált és intelligens hozammenedzselés, a növekedési indikátorok, a nem szisżtematikus és egyedi kockázatok menedzselése napjainkban különös jelentöséggel bír. A vizsgálat célja: pénzü̈gyi diagnózist készíteni. A vizsgálat tárgya: a magyarországi top cégeket magukban foglaló 'szálláshely-szolgáltatás és vendéglátás' ágazat. Az alkalmazott módszertan: eset-és adatbázis elemzés FINel diagnosztikai és értékalkotó rendszerrel, valamint az EkoWIN pénzüugyi elemzó, elörejelzó és vállalatértékelö számitógépes szakértöi rendszerrel. A vizsgált adatbázis: a magyar top 500 és a megyei top 1000 vállalatok szuurt ágazati mintája, amely mérleg és eredménykimutatásokat tartalmaz. A vizsgálat kérdései: A vizsgált cég vagy ágazat vajon jövedelmezó, miközben firetóképes, nem eladósodott, perspektivikus a müködése, valamint hatékony eszköz- és vagyongazdálkodást folytat? Hogyan változott a piaci pozíció térkép a jövedelmezóségi és kockázati mix függvényében? A pénzü̈gyi elemzésböl eredö diagnóziskészités keretében követkeatetni lehet a turizmus ágazat növekedési perspektiváira, pén zügyi esélyeire és finanszírozhatóságára. A vizsgálatunk eredményei segithetik a pén zügyi vezetök tervezési, menedzselési és kontrolling munkáját, itt különösen az IGR és SGR növekedési ráták vizsgálatát SNR ismeretében, az esžöz̧inanszírozás megfelelóségében, valamint a likviditás felügyeletében.

\section{SUMMARY}

We look at the economic sector that today has been achieved sales of over HUF 1,000 billion. We focus on the content of financial audit. Integrated and intelligent benefit management, growth indicators, nonsystematic and specific risk management are of particular importance today. The purpose of the study is to make a financial diagnosis. The subject of the study: is the 'accommodation and catering' sector, which includes the top Hungarian companies. Applied methodology: case- and database analysis with FINel Diagnostic and V alue Creation System and EkoWIN Financial Analyzer, Forecasting and Company Valuation Computer Expert System. Investigaterd database: is a filtered sectoral sample of the Hungarian top 500 and the county's top 1000 companies, which includes balance sheet and profit and loss accounts. The results of the study may help work financial decisions makers for planning, management, monitoring and controlling. The study question: Is the examined company or sector profitable, while it is solvency, non-indebted, perspective efficient asset management? How did the market position map change as a function of profitability and risk mix? In the framework of the diagnostic preparation resulting from the financial analysis, one can infer the growth prospects, financial chances and financing of the tourism sector. The results of our study can help financial managers to plan, manage and control, especially the IGR and SGR growth rates by knowing SNR, asset financing adequacy and liquidity management. 


\section{BEVEZETŐ}

A múltbelitől teljesen eltérő gyártástechnológiába való átlépést ipari forradalomnak hívják. Az új gyártási technológiák alapjaiban változtatják meg az emberek munkafeltételeit és életvitelét. Tanulmányom első fejezetében az eddigi ipari forradalmak alakulását tekintem végig, majd megvizsgálom fő témám, a 4. ipari forradalom különös sajátosságait.

Az egyik ilyen jelentős sajátosság a hálózat, mely okos eszközök sokaságát köti össze, így a kommunikációnak, távközlésnek kiemelt jelentősége van ebben a folyamatban, ez indokolja a telekommunikációs cégek vizsgálatát a téma keretében, így a továbbiakban ezen cégek pénzügyi mutatószámait fogom bemutatni. Megvizsgálom ezeknek a mutatószámoknak az alakulását, és pénzügyi standardokkal összevetve feltárom alakulásuk irányát (kedvező, vagy kedvezőtlen alakulását), majd ebből vonok le következtetéseket. Fontosnak tartom kiemelni, hogy a mutatószámrendszer vonatkozásában az adott ágazat/szektor sajátosságaira tekintettel indokolt a kapott adatokat értelmezni, így be fogom mutatni, hogy az általam vizsgált cégek mutatóinak értéke hogyan viszonyul a szakágazati vállalatok értékeihez képest. Elemzésem alapját a céginfo.hu oldalon található pénzügyi-számviteli beszámolók (mérleg, eredménykimutatás és kiegészítő melléklet) és a cégek honlapján szereplő információk alkotják. (Magyar Telekom Nyrt. (2018a), Telenor MagyarorszÁg ZRT. (2018b), Vodafone Magyarország Zrt. (2018c)).

\section{SZAKIRODALOMFELDOLGOZÁS}

A témaválasztásunknak a következő oka van: A magyar turizmus olyan stratégiai ágazat, amely napjainkban már 1000 milliárd forint feletti forgalmat teljesít. A turizmus jelentős mértékben járul hozzá Magyarországon a gazdaság élénkítéséhez és a munkahelyteremtéshez. A KSH szatellit számla adatai szerint 2018-ban a turizmus gazdasághoz való közvetlen hozzájárulása a GDP 6,8\%-a, a közvetett hatásokat is magába foglaló hozzájárulás pedig a GDP 10,7\%-a. A turisztikai ágazatokban betöltött állások száma 428 ezer fő, a munkahelyek 10,0\%-át a turizmus generálta közvetlenül, a közvetlen és közvetett hatásokat összesítve pedig a nemzetgazdasági foglalkoztatottság 13,2\%-át adja a turizmus (mtu.gov.hu, 2018).

A turizmus fontosságát mi sem bizonyítja jobban az, mint hogy 2018. év január és március időszakban mind a vendég éjszakák száma, mind pedig az általuk eltöltött vendégéjszakák száma 11\%-os emelkedést mutat az előző év azonos időszakához viszonyítva. A belföldi vendégek száma 13\%-kal haladta meg a tavalyi első negyedéves értékeket. A KSH által 2018-ban közzétett statisztika alapján az év első három hónapjában a kereskedelmi szálláshelyek 15\%-kal több bruttó bevételt realizáltak. Továbbá, a szobák kihasználtsága 3,5 százalékponttal volt nagyobb, mint egy évvel ezelőtt (ksh.hu, 2018).

Ebben a munkában a turizmus ágazat pénzügyi átvilágítás tartalmi jegyeire fókuszálunk. Az integrált és intelligens hozammenedzselés, a növekedési indikátorok, a nem szisztematikus és egyedi kockázatok menedzselése napjainkban különös jelentőséggel bír. 
A célunk: pénzügyi diagnózist készíteni. A vizsgálat tárgya: a magyarországi top cégeket magukban foglaló 'szálláshely-szolgáltatás és vendéglátás' ágazat. Az alkalmazott módszertan: eset- és adatbázis elemzés FINel pénzügydiagnosztikai és értékalkotó rendszerrel, valamint az EkoWIN pénzügyi elemző, előrejelző és vállalatértékelő számítógépes szakértői rendszerrel. A vizsgált adatbázis: a magyar top 500 és a megyei top 1000 vállalatok szűrt ágazati mintája, amely mérleg és eredménykimutatásokat tartalmaz.

A következő két kutatási kérdésre szeretnénk válaszolni: A vizsgált cég vagy ágazat vajon jövedelmező, miközben fizetőképes, nem eladósodott, perspektivikus a múködése, valamint hatékony eszköz- és vagyongazdálkodást folytat? Hogyan változott a piaci pozíció térkép a jövedelmezőségi és kockázati mix függvényében? A pénzügyi elemzésből eredő diagnóziskészítés keretében következtetni lehet a turizmus ágazat növekedési perspektíváira, pénzügyi esélyeire és finanszírozhatóságára.

\section{SZAKIRODALOMFELDOLGOZÁS}

A választott témánk hazai és nemzetközi szakirodalma nagyon gazdag, ezért itt kizárólag a vizsgálatunkhoz kapcsolódó szerzốk munkáját emeljük ki az alábbi két nézőpontra fókuszálva:

1. A pénzügyi elemzés logikai váza.

2. A mono- és multikauzális ok-okozati kapcsolatok vizsgálata.

A hatályos magyar számviteli törvény (netjogtar.hu, 2019) szerint: ...a vállalkozó vagyoni, pén zügyi és jövedelmi helyzetéról, annak változásáról a tényleges körülményeknek megfeleló, megbįható és valós képet kell mutatnia... értékelni kell a vállalkozó valós vagyoni, pénzügyi és jövedelmi helyzetét, az eszközök és a források összetételét, a saját tőke és a kötelezettségek tételeinek alakulását, a likviditás és a fizetóképesség, valamint a jövedelmezőség alakulását. Vajon a törvény készítői gondoltak arra, hogy az elemzés tartalma és logikai váza megfelelô, ahogyan az említett hatályos szöveget olvassuk?

FAZAKAS (2001) munkájában közli a jövedelmezőség mérését, a hatékonyságot, a vállalat piaci megítélését, az eladósodottságot, a likviditást, végül pedig a piaci pozíció vizsgálatát. SINKOVICS (2012) könyvében azt hangsúlyozza, hogy a pénzügyi mutatószámok jelentik a legfóbb gazdasági információs bázist és forrást a külső érdekelt gazdasági környezet számára. Ennek alapján döntenek a piaci szereplők a beruházásokról. A következők számítását tartja fontosnak: a jövedelmezőségi, tőkemegtérülési mutatók a legalapvetőbbek a vállalat megítélésben, az általános pénzügyi mutatók a mérleg alapján és az eredmény-kimutatásból adataiból képezzük (eszközszerkezeti mutatók, likviditási mutatók, forrásszerkezeti, tốkeáttételi mutatók, eszköz-forrásszerkezeti mutatók, hatékonysági mutatók, eladósodottsági mutatók, adósságszolgálati terhek, cash-flow mutatók).

TAKÁCS (2009) a számviteli tv. szerinti logikát követi, amit kiegészít a hatékonyság elemzésével, így négy vizsgálati területet különböztet meg. 
BREALEY-MYERS (1999) először a tőkeáttétel, aztán a likviditás, majd a jövedelmezőség vagy hatékonyság, végül pedig a piaci érték alakulását vizsgálja. Szeretnénk itt jelezni, hogy nem értünk egyet a 'vagy' kötőszó használatával, mert a jövedelmezőség és a hatékonyság elemzését nem cserélhetjük fel.

BODIE - MERTON - CLEETON (2011) szerint a vállalati teljesítményt öt fő szempontból elemezhetjük: a nyereségességi, az eszközhatékonysági, a pénzügyi tőkeáttételi, a likviditási és a piaciérték-hányados.

DAMODARAN (2006) a monokauzális ok-okozati kapcsolatok elemzését először az eszközök, majd a finanszírozási szerkezet, aztán az eredmény és a jövedelmezőség, végül pedig a kockázat mérése sorrendben végzi.

CHANDRA (2011) a következő sorrendet közli: likviditási, áttételi, hatékonysági, jövedelmezőségi és piaci értékelési ráták. Külön kiemeli az iparági adatok ismeretében történő időbeni összehasonlítást, vagyis a vertikális és horizontális elemzést. FAZEKAS (2001:83) véleménye is hasonló: „Egy vállalat működésének elemzése óhatatlanul az összehasonlításon alapul: a saját múltbeli adataihoz, vagy a vetélytársak, az adott iparágban tevékenykedő többi vállalat mutatóihoz képest milyen eredményeket mutat fel a mi vállalatunk."

Mindegyik megfogalmazásból kitűnik az, hogy a vállalkozás működésének elemzését a monokauzális ok-okozati kapcsolaton alapuló mutatószámok számításával és a kapott eredmények értékelésével szükséges megkezdeni. Azt viszont nem szabad elfelejteni, hogy nem mindegy milyen időszakot vizsgálunk. A vállalkozás mérlege az üzleti év adott időpontjára, míg az eredménykimutatás az üzleti év egészére vonatkoztatva tükrözi a vállalkozás helyzetét.

A - monokauzális ok-okozati összefüggéseken túllépő - multikauzális pénzügyi mutatószám rendszereknek két nagy csoportja létezik: analitikus és szintetikus. A multikauzális analitikus pénzügyi mutatószámrendszerekben egy ún. mutatószám-piramis keletkezik, amely megkönnyíti a mutatószám felépítését és kiértékelését a számolási interdependencián keresztül. A pénzügyi kiértékelésen kívül az információszerzés összefüggéseit is jól szemlélteti (Du Pont-rendszer, ZVEI mutatószámrendszer, Reichmann-Lachnit-rendszer). Ellenben kikapcsolja a döntésreleváns komponenseket, mivel azok a mutatókban nem dokumentálhatók, algebrailag más mutatókkal nem kapcsolhatók össze (BUCHNER, 1985).

A DuPont modell (DAvis - DAVIS, 2011; FABOZZI - MARKOWITZ, 2011) piramisformájú, matematikai összefüggéseken alapuló rendszer, amelyben a mutatószámok a ROA mint csúcsmutató tartalmát bontjuk fel. A ROA mutatószám piramis eredetileg kialakított rendszere részletes dokumentációra épül. Minden részleghez (profitcenterhez vagy divízióhoz) egy úgynevezett kontrolltáblázat tartozik, amely bemutatja a mutatószámok képzését és tartalmát, biztosítva ezáltal az alapadatok és a mutatószámok egységes tartalmát. E táblázatok alapján készül el a teljes - vállalati szintú - összegző táblázat, amely a mutatószámok végleges - összevont - értékeit foglalja magában. A modellt használják a tervezési és utólagos ellenőrzési eszközként is. A 
mutatószámrendszer előnyei közé soroljuk az egyszerűséget, az áttekinthetőséget és a gyors összeállíthatóságát. A DuPont mutatószámrendszernek egy rendkívül fontos érdeme: az általa végzett analízis lehetőséget ad arra, hogy összehasonlítsunk különböző méretű és ágazati profilban múködő vállalkozásokat. Ellenben nem tartalmaz likviditásra vonatkozó mutatókat.

A két lépéses DuPont modell:

$$
\begin{aligned}
R O A & =\frac{E A T}{\text { Total Assets }}=\frac{S N R}{\text { Total Assets }} \times \frac{E A T}{S N R} \\
\text { Eszközhatékonyság } & \text { Nettó jövedelmezöség } \\
\text { ROI } & =\frac{E A T}{\text { Investments }}=\frac{S N R}{\text { Investments }} \times \frac{E A T}{S N R} \mathbf{Y} \\
\text { Befektetések hatékonysága } & \text { Nettó jövedelmezőség }
\end{aligned}
$$

A háromlépéses DuPont modell:

$$
\mathrm{ROE}=\frac{E A T}{\text { Equity }}=\frac{S N R}{\text { Total Assets }} \times \frac{E A T}{S N R} \times \frac{\text { Total Assets }}{\text { Equity }}
$$

Eszközhatékonyság Nettó jövedelmezőség Finanszírozási szerkezet

Az ötlépéses DuPont modell:

$$
\mathrm{ROE}=\left(\frac{E A T}{E B T}\right) \times\left(\frac{E B T}{E B I T}\right) \times\left(\frac{E B I T}{S N R}\right) \times\left(\frac{S N R}{\text { Total Assets }}\right) \times\left(\frac{\text { Total Assets }}{\text { Equity }}\right)
$$

Adóteher Kamatteher Múködési Eszközhatékonyság Finanszírozási jövedelmezőség

szerkezet

ahol

EAT $=$ Earnings after $\boldsymbol{T}$ axes $=$ Adózás utáni eredmény

EBT $=$ Earnings before $\boldsymbol{T}$ axes $=$ Adózás előtti eredmény

EBIT $=$ Earnings $\boldsymbol{b}$ efore Interest and $\boldsymbol{T}$ axes $=$ Kamat- és adófizetés utáni eredmény

$\mathrm{SNR}=$ Sales $\boldsymbol{N}$ et $\boldsymbol{R}$ evenue $=$ Értékesítés nettó árbevétele

Total Assets = Összes eszköz

Investments $=$ Befektetések

Equity $=$ Saját tőke 


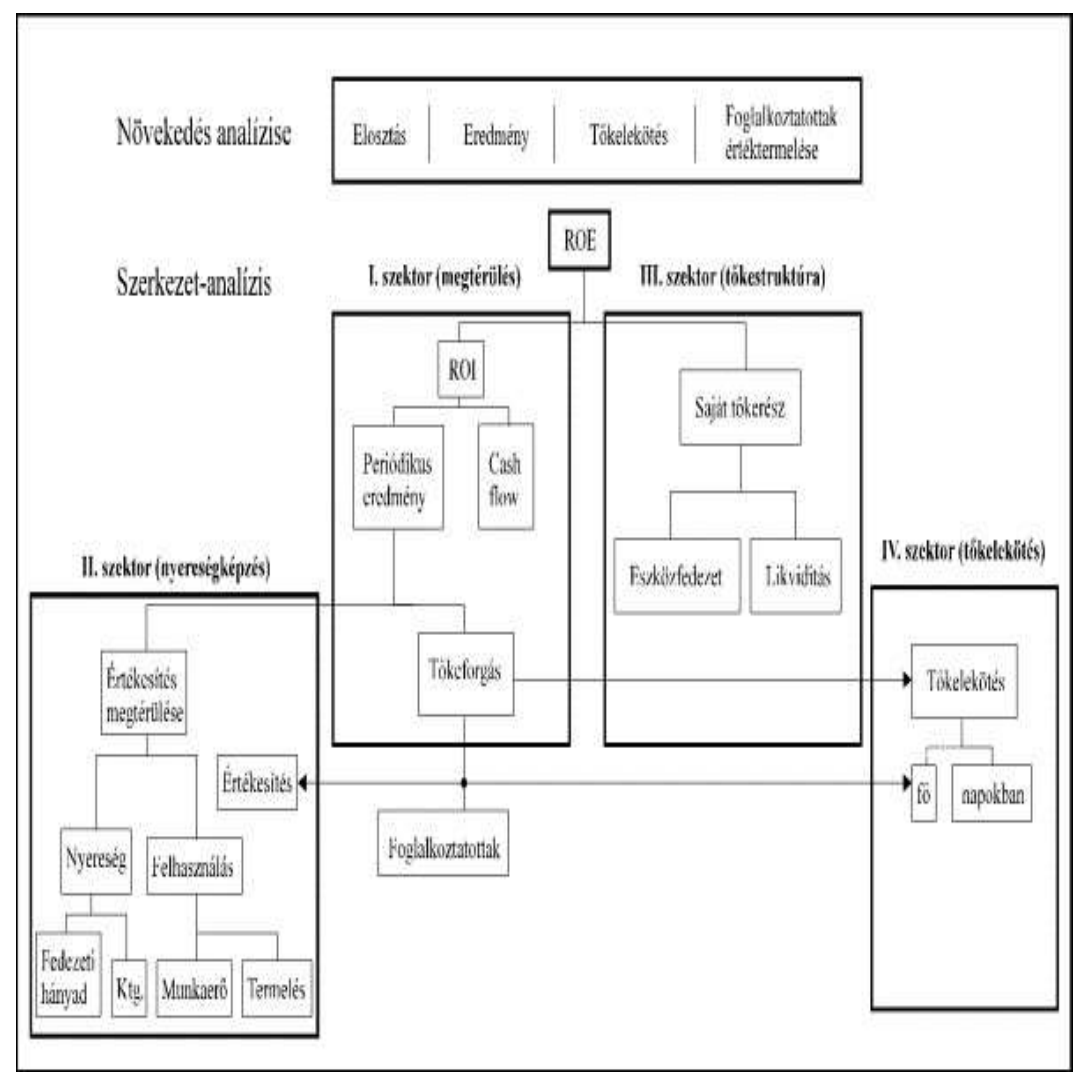

1. ábra. A ZVEI (Zentralverband der Elektronischen Industrie) mutatószámrendszer Forrás: KATTTS, 2010: 342.

A ZVEI mutatószámrendszer (1. ábra) - a DuPont modellhez hasonlóan - egy mutatószám-piramis. A mutatószámok között nemcsak matematikai, hanem tartalmi összefüggések vannak. A rendszer a mutatókat fő- és segédmutatókra osztja fel (összesen 210 egyedi mutatószámot tartalmaz, ezen belül 88 fő- és 122 segédmutatóból áll). A főmutatók kijelölik az elemzés területeit és meghatározzák a további elemzések tartalmát. A segédmutatók szerepe csupán az, hogy a főmutatókat matematikailag alátámasszák, illetve formai összefüggéseket teremtsenek a főmutatók között. A rendszer viszonyszámokat és abszolút adatokat egyaránt tartalmaz. Felhasználja a számviteli beszámoló, valamint a költségek és teljesítmények, a belső eredményszámítások adatait. Érdemes megjegyezni azt, hogy bár az elektronikai ipar területén dolgozták ki, más ágazatok vállalkozásai esetében is alkalmazhatjuk. A szerkezetét nem módosíthatjuk, így viszonylag rugalmatlan. A ZVEI modell vegyes mutatószámrendszer. Egyrészt a vállalat növekedését értékeli, másrészt pedig a gazdálkodás különböző megközelítésű, párhuzamosan végzett vizsgálatát jelenti. Elemzéshez és tervezéshez is egyaránt alkalmazhatjuk. 


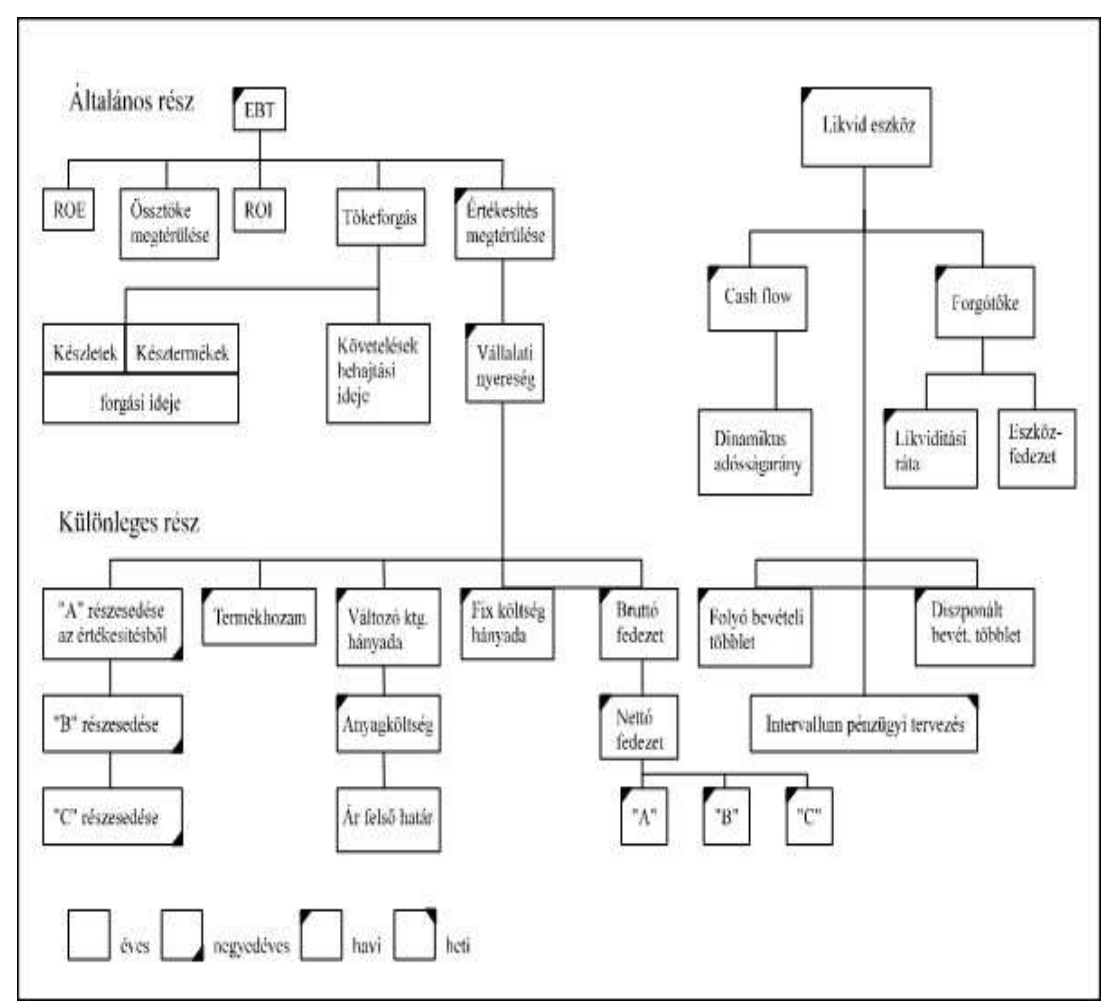

2. ábra. Az RL (Reichmann - Lachnit) mutatószámrendszer

Forrás: Katits, 2010, 343.

Az RL mutatószámrendszer (2. ábra) a vállalkozás jövedelmezőségi és likviditási helyzetét koncentrált formában vizsgálja. A mutatószámrendszer összesen 39 mutatószámból áll és mind viszonyszámokat, mind pedig abszolút számokat alkalmaz a pénzügyi és a vezetői számvitel adataira egyaránt építve. A rendszer tartalmilag rendezett (rendszeralapú), az elemeit (mutatószámait) nem matematikailag, hanem tartalmi szempontok szerint kapcsolja össze. Az RL rendszer az alábbi két alapvető részből áll:

- Általános rész: állandó, általánosan minden vállalkozás számára alkalmas mutatókat tartalmaz, egyaránt felhasználható tervezéshez, elemzéshez, az értékeléshez és ezeken keresztül az irányításhoz.

- Különleges rész olyan mutatószámokat foglal magában, amelyek cégspecifikusak és - tartalmuknak megfelelően - kiegészítik az értékelést (tekintetbe véve azok hatását a jövedelmezőségi és likviditási legfelsőbb célértékekre).

Az RL modell rugalmasnak tekinthető, kiválasztható mutatószámokból épül fel, amelyek az adott vállalkozás profiljának megfelelően alakítható. Figyelembe veszi azt is, hogy a mindenkori fizetőképesség fenntartása lényeges követelmény egy társaság esetében.

Mindhárom mutatószámrendszer eszköze lehet a vállalkozások tervezésének, az irányításának és ellenőrzésének is, ugyanakkor része lehet és segítségül szolgálhat az éves beszámoló elemzési módszertanának. 
A szintetikus mutatószám-rendszerek egyrészt empirikus vizsgálatok, másrészt pedig matematikai-statisztikai módszerek felhasználására épülnek. Például a vállalati fejlődés mértékét kifejező üzleti indexet meghatározó pénzügyi ráták súlya és kiválasztása az elemző szubjektív értékítéletén alapul, illetve a releváns mutatószámok kiválasztása faktor-, klaszteranalízissel, a mutatószámok súlyozása és index képzése a diszkriminancia analízis eszközével történik, hasonlóképpen a csődelőrejelző modellek családja esetében (GEBHARDT, 1980; ALtMAn, 1988; KATITS, 2010; KATITS-PogÁtSA-ZsuPANEKNÉ, 2017).

A szakirodalmi áttekintésben feltártuk a mono- és multikauzális ok-okozati összefüggéseken alapuló mutatószámok rendszerének lehetséges csoportosítását, de mindezt kiegészítjük a 4. részben közreadott módszertani sajátosságokkal.

\section{ANYAG ÉS MÓDSZER}

Mind az oktatásban, mind pedig a kutatásban már évek óta prezentálunk eltérő életszakaszokban levő hazai vállalati eset (Abo Mill Zrt., Albacomp Zrt., Barnevál Kft., Cerbona Zrt., Cornexi Zrt., Enefi Nyrt., Herendi Zrt., Herz Zrt., Vectigalis Zrt., Zsolnay Zrt.) és adatbázis (csőd- és felszámolási eljárás alatt álló, 90 magyar termelő-kereskedő társaság esete, a nettó értékesítési árbevétel alapján a hazai top 100, 500 és 5000, valamint a KKV-szektorba tartozó legnagyobb 2775 vállalkozás mérleg és eredménykimutatás tételei) elemzésével kapott eredményeket. Nagy érdeklődéssel elemezzük az eltérő életszakaszokban levő, kettős könyvvezetési kötelezettség alá tartozó cégek adatbázisait. Ebben a munkában egyrészt a legnagyobb - a Heti Világgazdaság rangsora alapján a top 500-ból a turizmus ágazatba tartozó 3 cég - DH, D és APH jelöléssel - mérleg és eredménykimutatásait elemezzük, amelyben kitérünk a 2008-tól jelentkező pénzügygazdasági válság hatásainak feltárására, mivel ezek ismerete éppen segíti vagy segítheti újabb növekedési perspektívák és utak, valamint forgatókönyvek felvázolását. Másrészt a Központi Statisztikai Hivatal (KSH) által készített adatbázist elemezzük. Ez az adatbázis felöleli az értékesítés nettó árbevétele szerint rangsorolt megyei top 1000 hazai és külföldi tulajdonú cégek mérleg és eredménykimutatás adatait. Mivel a 3 szálloda székhelye Budapest, ezért maradunk ebben a régióban, így a Budapest és a pest megyei top 1000 ágazati mintájának azonosítására rendelkezésre állt a TEÁOR (Tevékenységek Egységes Ágazati Osztályozási Rendszere) 55 'szálláshely szolgáltatás' és 56 'vendéglátás' ágazati adatok.

Mivel az adatbázis mérleg és eredménykimutatás fóbb sorait tartalmazta, ezért az időpontra vonatkozó mérlegtételek éves átlagolt értékeit már összevethettük az üzleti évet felölelő eredménykimutatás megfelelő adataival.

Az 1. táblázat mutatja a 3 vizsgált szálloda helyezésének változást 2007 és 2016 között. A legnagyobb rangsor helyezési változásokat az APH mutatja, amely éppen a top 500 rangsor hátsó részében áll a másik két szállodához képest. Az is szembetűnő, hogy egyik szálloda sem érte el a 2008. globális pénzügygazdasági válság előtti helyezést. 
1. táblázat. A vizsgált szálloda helyezésének változása 2007 és 2016 között

\begin{tabular}{lcccccccccc}
\hline Megnevezé & $\mathbf{2 0 0}$ & $\mathbf{2 0 0}$ & $\mathbf{2 0 0}$ & $\mathbf{2 0 1}$ & $\mathbf{2 0 1}$ & $\mathbf{2 0 1}$ & $\mathbf{2 0 1}$ & $\mathbf{2 0 1}$ & $\mathbf{2 0 1}$ & $\mathbf{2 0 1}$ \\
$\mathbf{s}$ & $\mathbf{7}$ & $\mathbf{8}$ & $\mathbf{9}$ & $\mathbf{0}$ & $\mathbf{1}$ & $\mathbf{2}$ & $\mathbf{3}$ & $\mathbf{4}$ & $\mathbf{5}$ & $\mathbf{6}$ \\
\hline $\mathbf{D H}$ & 154 & 175 & 166 & 180 & 187 & 182 & 172 & 170 & 173 & 161 \\
$\mathbf{D}$ & 243 & 306 & 293 & 331 & 356 & 349 & 333 & 340 & 342 & 330 \\
$\mathbf{A P H}$ & 319 & 418 & 428 & 484 & 488 & 498 & 468 & 463 & 460 & 451 \\
\hline \multicolumn{7}{c}{ Forrás: saját szerkesztés a Heti Világgazdaság által közölt adatok alapján }
\end{tabular}

A vizsgált időszakban az alkalmazotti létszámadatok a DH esetében 126-ról 21-re, a D nél 2815 főről 2 267-re és az APH estében 1171 főről 916 főre csökkent, amelyet a racionalizálás eredményének tekintünk, de arra a kérdésre, hogy ez vajon összekapcsolódott-e a gazdálkodás javulásával, az 5. részben adunk választ.

A TOP 500 és a megyei TOP 1000 adatbázis Excel táblázatkezelő programmal készült. Az alkalmazott pénzügyi módszertan a mono- és multikauzális ok-okozati kapcsolatok feltárásán alapuló számítások, amelyek közül célirányosan választottunk. A számításokat a saját fejlesztésű FINel diagnosztikai és értékalkotó szakértői rendszerrel végeztük, amelynek tartalmát a 3. ábra szemlélteti. A FINel alkalmas a vállalati működés fázisaihoz - az originális és derivatív alapítás, a növekedés és válság szakaszokhoz - igazított elemzést végezni a 3. ábrában közölt logika mentén, de a három elemzési modulját önállóan is lehet alkalmazni. Ezt bizonyítja Kucséber (2016) Hitelintézeti Szemle és Kucséber (2015) Tér-Gazdaság-Ember című szaklapban megjelent munkájában.

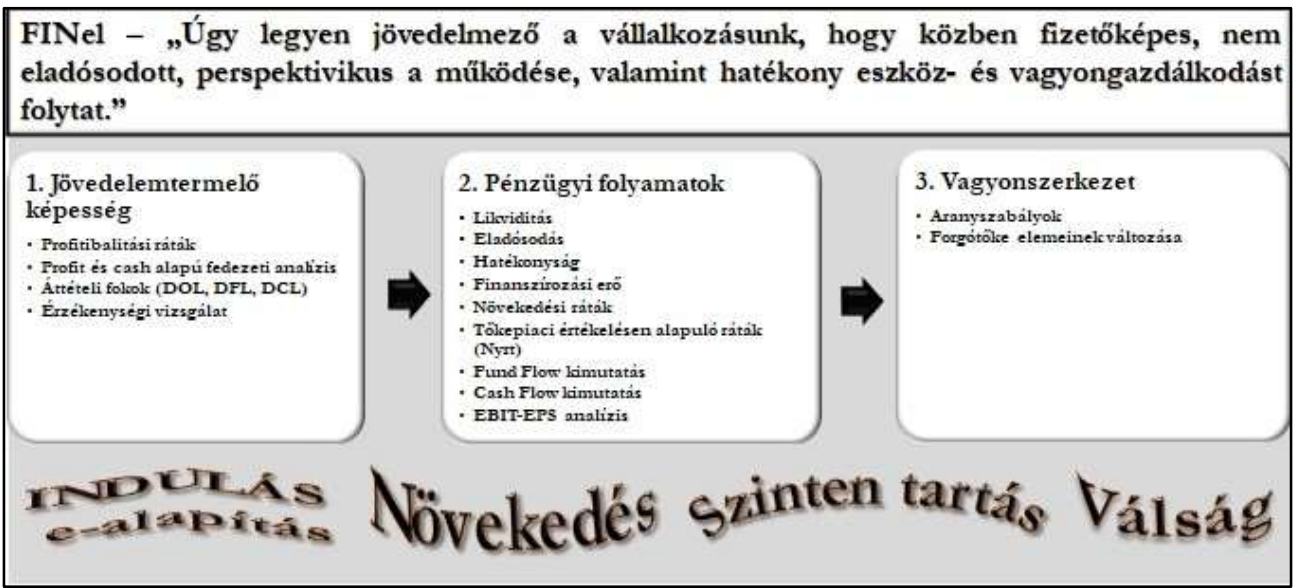

3. ábra. A FINel pénzügyi szakértői rendszer elemzési és diagnóziskészítő moduljai Forrás: saját szerkesżtés

Akár a szálloda, akár a régió életképességének és eredményességének legfőbb forrása a tevékenységének árbevételt generáló képessége. Több információt nyerünk ezzel kapcsolatban akkor, ha az alábbi három módon is vizsgálódunk: 
1. A belső növekedésre akkor képes a szálloda, ha teljes mértékben külső források igénybevétele nélkül, önfinanszírozó módon éri el, vagyis a finanszírozási források kizárólag a profitvisszatartásból származnak (CHANDRA, 2011; PARRINO - MOLES KIDWELL, 2016).

$$
I G R=\frac{\frac{\text { Net Profit }}{\text { Assets }} \times \frac{\text { Retained Profit }}{\text { Net Profit }}}{1-\frac{\text { Net Profit }}{\text { Assets }} \times \frac{\text { Retained Profit }}{\text { Net Profit }}}=\frac{R O A \times R P R}{1-\text { ROA } \times R P R}
$$

2. A fenntartható növekedés (SGR $=$ Sustainable Growth $\boldsymbol{R}$ ate) esetén a vizsgált cég tőkeszerkezete úgy marad változatlan, hogy a társaság nem bocsát ki - nyilvánosan - új, pótlólagos részvényeket. Ez tehát olyan növekedés, amely új saját tőke bevonása nélkül, a hosszú lejáratú kötelezettségek és a saját tőke arány megtartása mellett érhető el (BABCOCK, 1970; Higgins, 1981; VAN HORNE - WACZHOWICZ; 2008, CHANDRA, 2011).

$$
S G R=\frac{\frac{\text { Net Profit }}{\text { Equity }} \times \frac{\text { Retained Profit }}{\text { Net Profit }}}{1-\frac{\text { Net Profit }}{\text { Equity }} \times \frac{\text { Retained Profit }}{\text { Net Profit }}}=\frac{R O E \times R P R}{1-R O E \times R P R}
$$

3. Az önfinanszírozható növekedés (SFGR $=$ Self-financeable $\boldsymbol{G}$ rowth $\boldsymbol{R}$ ate) az operatív módon kigazdálkodott forrásokkal - külső finanszírozás és tőkekivonás nélkül - elérhető vállalati növekedés (Churchill - Mullins, 2001, Marks - Robbins - Fernandez Funkhoser -Williams, 2009). Ez a vállalat-specifikus növekedési ráta alapvetően az alábbi 3 tényezőtől függ:

- A működési cash ciklus (OCC = Operating Cash Cycles) időtartama, ami a készlettartás ideje (DIH = Days Inventory $\boldsymbol{H}$ eld $)$ és a vevői követelések behajtási ideje (DSO = Days $\boldsymbol{S}$ ales $\boldsymbol{O}$ utstanding).

- A forráslekötés időtartama OCC-ként a forgótőke finanszírozás érdekében.

- A szabadon rendelkezésre álló forrás generálása OCC-ként.

A következő lépések szükségesek az éves SFGR számításához:

$$
\begin{aligned}
& \frac{\frac{\text { Szabadon rendelkeezésre álló forrás }}{\text { SNR }}}{D I H+D S O}=\text { SFGR OCC-ként }\left(=S F G R_{O C C}\right) \\
& \frac{365}{O C C}=O C C-k \text { száma éves szinten }\left(=O C C_{n}\right)
\end{aligned}
$$

$$
\left(1+S F G R_{o c c}\right)^{O C C_{n}}-1=\text { Éves SFGR }
$$


Itt megjegyezzük azt, hogy egyrészt az IGR és SGR növekedési ráták nagyságát közvetlenül befolyásoló tényezők, vagyis a ROA (Return on $\boldsymbol{A}$ ssets) és a ROE (Return on $\boldsymbol{E}$ quity) összetevőinek, így a növekedési lehetőségek pénzügyi elemzését a 2. pontban már közreadott DuPont modell keretében is lehet végezni. Másrészt az értékesítési kockázat (m)értékét, a növekedési perspektívák finanszírozhatóságát az IGR, az SGR és az SFGR növekedési ráták ismeretében érdemes elemezni úgy, hogy a tervezett vagy a tényleges értékesítési árbevétel változását ( $\mathrm{SaGR}=\boldsymbol{S}$ ales $\boldsymbol{G}$ rowth $\boldsymbol{R}$ ate) is tekintetbe vesszük. Harmadrészt pedig 3 árbevétel növekedési ráta számításával ki lehet dolgozni a növekedés pénzügyi forgatókönyvének alapjául szolgáló eredménykimutatás tervezetét (Katits, 2017b).

A másik saját fejlesztésú szoftver az EkoWIN pénzügyi elemző, előrejelző és vállalatértékelő számítógépes szakértői rendszer, amely minden eredményt kétféleképpen minősít" durván" egy ötfokozatú A-B-C-D-E skálán, és "finoman" egy 0 és 100 közötti, egytizedes pontosságú, teljesítménypontnak nevezett értékkel. Az ötfokozatú skála jelentése: $(\mathrm{E})=$ kritikus; $(\mathrm{D})$ = problematikus; $(\mathrm{C})$ = elfogadható; $(\mathrm{B})$ = jó; $(\mathrm{A})$ = kiváló. A szoftver minden számított értékhez előre definiál hat darab küszöbértéket. A küszöbök között levő értékekhez tartozó teljesítménypontot a program lineáris interpolációval számolja ki. Az egy-egy modulba tartozó számításokkal kapott értékek teljesítménypontja az adott modulba szereplő egyedi számítások teljesítménypontjainak a rendszerben előre definiált súlyokkal számított átlaga. (Az átlagképzésben felhasznált súlyok a számítások fontosságát, jelentőségét fejezik ki.) Egy-egy modul A-B-C-D-E minősítése, az átlagos teljesítménypont alapján, a következő módon történik: 0 - 19,9 p = (E) = kritikus; 20 $39,9 \mathrm{p}=(\mathbf{D})=$ problematikus; $40-59,9 \mathrm{p}=(\mathrm{C})=$ elfogadható; $60-79,9 \mathrm{p}=(\mathbf{B})=$ jó; $80-100,0 \mathrm{p}=(\mathbf{A})=$ kiváló. Az 5-7. ábrákon a megadott színek is jelzik a minősítést. A szoftver a komplett jövedelmezőségi és kockázati mix értékelésekor hasonlóan jár el: az I-III. (4. táblázat) és az I-V. modul (5. tábláąat) átlagos teljesítménypontjait előre definiált súlyokkal "tovább átlagolja", majd az átlagot betűvel is minősíti. Az összértékelés finomított besorolása azt jelenti, hogy az elért betú által reprezentált 20 pontos sáv melyik negyedébe esik a kapott pontszám (annyi „csillag” jelenik meg a betű után). A példa kedvéért $\mathbf{B} * *$ azt jelenti, hogy a cég 65 - 69,9 teljesítménypont tartományban van.

A 4. ábra egyrészt szemlélteti a jövedelmezőségi és a kockázati mix moduljait, másrészt pedig a modulok alapján, a kapott minősítési pontszámok ismeretében, piaci pozíció térképet is lehet készíteni. 


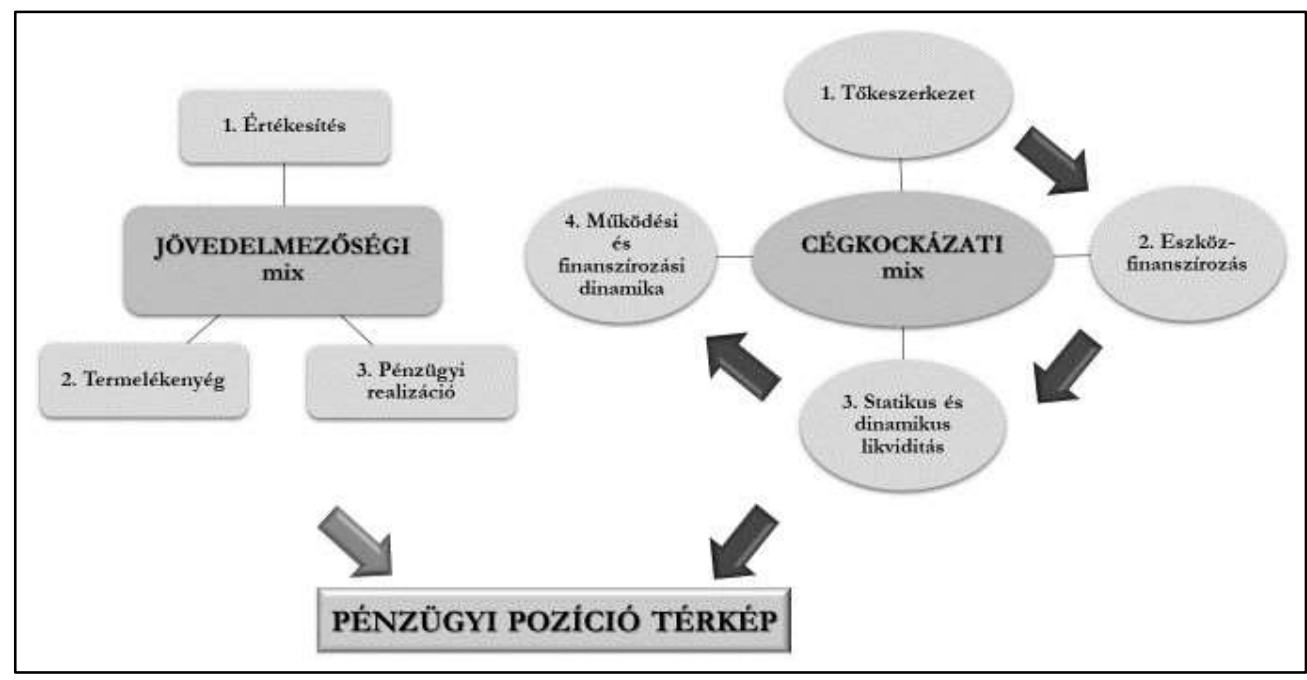

4. ábra. Az EkoWIN pénzügyi elemző, előrejelző és vállalatértékelő számítógépes szakértői rendszer 3 elemzési és diagnóziskészítő modulja

Forrás: saját szerkesztés

Ezt a módszertani részt a következő megjegyzéssel zárjuk: Hangsúlyozni szeretnénk a különbséget a 'pénzügyi elemzés' és a 'vállalati elemzés' között. Használjuk a 'pénzügyi elemzés' megnevezést a vállalati mérleg, az eredménykimutatás és a cash flow kimutatás célirányos és logikai keretben történő elemzésére, míg a 'vállalati elemzés' megnevezést a vállalat - komplex és szűkebb értelemben vett - átvilágítására! Amennyiben a 'vállalati elemzés’ készítése a cél, úgy annak kiindulópontja az éves beszámoló adatainak teljes kiértékelése, amelynek logikai vázát és tartalmát jelentheti akár a FINel, akár az EkoWIN szakértői rendszer. A tágan értelmezett vállalati elemzés azonban nemcsak a gazdálkodás (jövedelemtermelőképesség, pénzügyi folyamatok, vagyonszerkezet) statikus (időponti) és dinamikus (időtartam) értékelését foglalja magában, hanem tartalmazza a vállalat különböző tevékenységi síkjának (emberi erőforrás, beszerzés-termelés-értékesítés stratégiai és operatív elemzés, vállalati vezetés és ügyvitel, vevők-szállítók-versenytársak, vállalkozásfejlesztés és eszközgazdálkodás elemzése, de profiltól függően a termelési, áruforgalmi és szolgáltatási tevékenység stb.) beható tanulmányozását is.

\section{EREDMÉNYEK}

Itt a FINel pénzügyi szoftvernek a multikauzális ok-okozati összefüggés feltárására épülő két-, három- és ötlépéses DuPont modelljét alkalmazzuk 3 szállodára, s kiegészítjük Budapest és Pest megye ágazati adatokkal a pénzügyi „bemérés” és diagnóziskészítés érdekében. Az illusztrációhoz a 2016. évi beszámoló adataival számoltunk (2. táblázat). A közreadott táblázatokban a működés gyenge pontjait szürke háttérrel jelöljük.

A ROA tényezőkre bontása alapján könnyen felismerhetjük azt, hogy vajon a probléma az eszközhatékonysággal vagy pedig a nettó jövedelmezőséggel kapcsolatos. Az eszközhatékonyság a felhasznált eszközállomány kihasználásának fokát fejezi ki. Ennek 
nagysága a DH cégnél nagyon alacsony, de az ágazat eszközeinek is csak bő 50 százaléka generál árbevételt. A nettó jövedelmezőség a társaság által egy adott időszakban elért adózott eredményt az értékesítési árbevételhez viszonyítja. Tehát ez az arányszám egészen átfogó módon vall arról, hogy a cég tevékenységének egészét figyelembe véve mekkora forgalomarányos nettó haszonnal dolgozik. Sajnos, a $\mathbf{D H}$ cég veszteséges, míg a két másik versenytárs nyereséges, bár a $\mathbf{D}$ cég nem éri el az ágazati értéket. Ha a vizsgált ágazat/cég nettó jövedelmezősége csökkenő tendenciájú, akkor ez figyelmeztető jel lehet. Ilyen esetekben alaposabban meg kell vizsgálni azt, hogy vajon az alaptevékenység haszonkulcsa romlott-e, esetleg a központi adminisztrációs és értékesítési költségek emelkedtek-e, vagy pedig a magas kamatköltségek rontják a nettó jövedelmezőséget.

A ROE értékét szétbonthatjuk a ROA és a részvénytőke szorzó (finanszírozási szerkezet) nagyságára. Itt a finanszírozási szerkezetet úgy értelmezzük, hogy az összes eszközt (a mérlegegyezőség miatt összes forrást) elosztjuk a saját tőke nagyságával. Ha ez az érték 1-nél nagyobb, akkor a vizsgált cég/ágazat a saját tőke mellé egyre több idegen forrást is bevont. Ez utóbbit tapasztaljuk, de az APH szálloda valamivel meghaladta az ágazati adatokat, vagyis relatíve magas idegen forrásnagysággal finanszírozta eszközeit.

2. táblázat. A két-, három- és ötlépéses DuPont modell alkalmazása benchmark vizsgálatban a 2016. üzleti évben

\begin{tabular}{ccccc}
\hline Megnevezés & $\mathbf{D H}$ & $\mathbf{D}$ & $\mathbf{A P H}$ & $\mathbf{M e g y e}$ \\
\hline Eszközhatékonyság & 0,08 & 0,80 & 0,78 & 0,56 \\
Nettó jövedelmezőség (\%) & $-48,90$ & 8,31 & 10,04 & 9,58 \\
\hline ROA & $\mathbf{- 3 , 8 4 \%}$ & $\mathbf{6 , 6 4 \%}$ & $\mathbf{7 , 8 1 \%}$ & $\mathbf{5 , 4 0 \%}$ \\
\hline Eszközhatékonyság & 0,08 & 0,80 & 0,78 & 0,56 \\
Nettó jövedelmezôség (\%) & $-48,90$ & 8,31 & 10,04 & 9,58 \\
Finanszírozási áttétel (Részvénytőke & 1,34 & 1,64 & 2,33 & 2,28 \\
szorzó) & & & & \\
\hline ROE & $\mathbf{- 5 , 1 5 \%}$ & $\mathbf{1 0 , 9 1 \%}$ & $\mathbf{1 8 , 1 8 \%}$ & $\mathbf{1 2 , 2 3 \%}$ \\
\hline Adóteher ráta & 1,00 & 1,00 & 0,93 & 0,95 \\
Kamatteher ráta & $-0,37$ & 0,96 & 1,00 & 0,88 \\
Múködési jövedelmezőség (\%) & 132,77 & 8,62 & 10,80 & 11,35 \\
Eszközhatékonyság & 0,08 & 0,80 & 0,78 & 0,56 \\
Finanszírozási áttétel (Részvénytóke & 1,34 & 1,64 & 2,33 & 2,28 \\
szorzó) & & & & \\
\hline ROE & $\mathbf{- 5 , 1 5 \%}$ & $\mathbf{1 0 , 9 1 \%}$ & $\mathbf{1 8 , 1 8 \%}$ & $\mathbf{1 2 , 2 3 \%}$ \\
\hline Lekötött tőke hatékonysága & 0,86 & 0,89 & 1,82 & 0,71 \\
Nettó jövedelmezőség (\%) & $-48,90$ & 8,31 & 10,04 & 9,58 \\
\hline ROI & $\mathbf{- 4 , 2 0 \%}$ & $\mathbf{7 , 3 9 \%}$ & $\mathbf{1 8 , 3 0 \%}$ & $\mathbf{6 , 7 7 \%}$ \\
\hline
\end{tabular}

Forrás: saját számításon alapuló szerkesztés a https://e-

beszamolo.im.gov.hu/oldal/beszamolo_kereses és KSH-adatbázisból 
A ROE rátát öt tényezőre lehet felbontani (Fabozzi - Markowitz, 2011). Ha a működési profithányad és az eszközhatékonyság, valamint az adóteher- és a kamatteher ráta értéke növekszik, akkor csökken a társasági adófizetési kötelezettség és a fizetendő kamatok és kamatjellegű ráfordítások nagysága.

A ROA tényezőkre bontása alapján könnyen felismerhetjük azt, hogy vajon a probléma az eszközhatékonysággal vagy pedig a nettó jövedelmezőséggel kapcsolatos. Az eszközhatékonyság a felhasznált eszközállomány kihasználásának fokát fejezi ki. Ennek nagysága a DH cégnél nagyon alacsony, de az ágazat eszközeinek is csak bő 50 százaléka generál árbevételt. A nettó jövedelmezőség a társaság által egy adott időszakban elért adózott eredményt az értékesítési árbevételhez viszonyítja. Tehát ez az arányszám egészen átfogó módon vall arról, hogy a cég tevékenységének egészét figyelembe véve mekkora forgalomarányos nettó haszonnal dolgozik. Sajnos, a DH cég veszteséges, míg a két másik versenytárs nyereséges, bár a $\mathbf{D}$ cég nem éri el az ágazati értéket. Ha a vizsgált ágazat/cég nettó jövedelmezősége csökkenő tendenciájú, akkor ez figyelmeztető jel lehet. Ilyen esetekben alaposabban meg kell vizsgálni azt, hogy vajon az alaptevékenység haszonkulcsa romlott-e, esetleg a központi adminisztrációs és értékesítési költségek emelkedtek-e, vagy pedig a magas kamatköltségek rontják a nettó jövedelmezőséget.

A ROE értékét szétbonthatjuk a ROA és a finanszírozási szerkezet (vagy részvénytőke szorzó) nagyságára. Itt a finanszírozási szerkezetet úgy értelmezzük, hogy az összes eszközt (a mérlegegyezőség miatt összes forrást) elosztjuk a saját tőke nagyságával. Ha ez az érték 1-nél nagyobb, akkor a vizsgált cég/ágazat a saját tőke mellé egyre több idegen forrást is bevont. Ez utóbbit tapasztaljuk, de az $\mathbf{A P H}$ szálloda valamivel meghaladta az ágazati adatokat, vagyis relatíve magas idegen forrásnagysággal finanszírozta eszközeit.

A ROE ráta öt tényezős felbontásában, ha a múködési profithányad és az eszközhatékonyság növekszik, valamint az adóteher- és a kamatteher ráta értéke közelít az 1-es értékhez, akkor a társasági adófizetési kötelezettség és a fizetendő kamatok és kamatjellegű ráfordítások nagysága csökken.

A 3. táblázat szürke háttérrel jelölt értékei négy dologra utalnak: 1. Ha az SaGR negatív, akkor egyik évről a másik évre csökkent az értékesítés nettó árbevétele, ami nagyon érzékenyen érintette a szállodákat. 2. Ha az IGR, SGR és az SFGR növekedési ráták negatívak, akkor a szálloda az adott évben vagy veszteséges, így a ROA és a ROE negatív, de szabadon rendelkezésre álló forrás sem áltt rendelkezésre, vagy pedig nem képződött visszatartott profit. 3. Ha az SaGR < IGR, akkor a szálloda nem használja ki azt a növekedési lehetőséget, ami az önfinanszírozásból, vagyis a visszatartott profitból adódna. Ez utalhat alacsony jövedelemtermelésre, ami a magas működési és finanszírozási költséghányadból ered; múködési és finanszírozási zavarokra az elégtelen forgótőke miatt; piaci problémákra a változó és/vagy csökkenő keresletből eredően; menedzselési gondokra. Ezt látjuk a DH esetében 2007-ben, 2010-ben, 2014-ben, az APH esetében 2014 és 2015 között. 4. Ha SaGR > SGR, akkor a szálloda hitelfelvétellel és/vagy tulajdonosi tőke bevonásával is finanszírozhatta a növekedést, de ezen kívül ezt a növekedést belülről (a profit visszaforgatásával, az eszközhatékonyság fokozásával) is 
biztosíthatta. Ebben az esetben egyaránt történhetett idegen és tartós tőkebevonás, vagyis ilyenkor a tulajdonosi kör is változhatott. Ezt a magas értékesítési nettó árbevétel növekedést több tényező okozhatta: a piaci kereslet növekedése, az áremelés, az eszközhatékonyság javítása, a működési költségek csökkentése a tevékenységek racionalizálásával akár szervezetfejlesztés keretében javítása. Ezt látjuk a $\mathbf{D H}$ esetében 2011-ben, 2012-ben, 2015-ben, az APH esetében 2007-ben és 2011-ben.

3. táblázat. A belső (IGR), fenntartható (SGR) és az önfinanszírozható (SFGR) növekedési ráta, valamint az eredménykimutatás értékesítés nettó árbevétel növekedési rátáinak (SaGR) alakulása 2007 és 2016 között (\%)

\begin{tabular}{lcccccccccc}
\hline \multicolumn{1}{c}{ Megnev. } & 2007 & $\mathbf{2 0 0 8}$ & $\mathbf{2 0 0 9}$ & $\mathbf{2 0 1 0}$ & $\mathbf{2 0 1 1}$ & $\mathbf{2 0 1 2}$ & $\mathbf{2 0 1 3}$ & $\mathbf{2 0 1 4}$ & $\mathbf{2 0 1 5}$ & $\mathbf{2 0 1 6}$ \\
\hline \multicolumn{8}{c}{} & \multicolumn{8}{c}{ DH } \\
SaGR & 0,18 & 6,02 & $-27,30$ & 1,38 & 3,62 & 3,76 & $-1,88$ & 3,05 & 10,53 & 9,25 \\
IGR & 1,55 & $-0,30$ & 0,14 & 1,42 & 1,04 & 1,88 & $-1,12$ & 7,22 & 0,00 & $-3,69$ \\
SGR & 2,27 & $-0,42$ & 0,19 & 1,93 & 1,42 & 2,51 & $-1,42$ & 9,04 & 0,00 & $-4,90$ \\
SFGR & $*$ & $*$ & $*$ & $*$ & $*$ & $*$ & $*$ & $*$ & $*$ & -100 \\
\hline
\end{tabular}

* A minimális a készletérték miatt az éves SFGR rendkívül magas érték.

\begin{tabular}{|c|c|c|c|c|c|c|c|c|c|c|}
\hline \multicolumn{11}{|c|}{ D } \\
\hline SaGR & $-3,55$ & $-5,32$ & $-11,27$ & $-2,39$ & 0,50 & 3,48 & 6,30 & 5,37 & 7,56 & 8,97 \\
\hline IGR & 0,01 & $-2,67$ & $-1,52$ & $-2,34$ & $-2,69$ & $-2,91$ & $-1,75$ & 0,00 & 0,00 & 7,11 \\
\hline SGR & 0,01 & $-3,49$ & $-2,01$ & $-3,03$ & $-3,53$ & $-3,87$ & $-2,36$ & 0,00 & 0,00 & 12,25 \\
\hline SFGR & 5,30 & 0,89 & 3,86 & 3,27 & 2,17 & 1,12 & 4,41 & 8,07 & 7,88 & 24,50 \\
\hline \multicolumn{11}{|c|}{ APH } \\
\hline $\mathrm{SaGR}$ & 16,47 & $-7,02$ & $-17,38$ & $-0,34$ & 6,31 & $-0,91$ & 6,61 & 9,12 & 7,80 & 8,45 \\
\hline IGR & 0,66 & $-1,29$ & $-11,61$ & $-12,79$ & 2,14 & $-0,07$ & $-6,04$ & 9,14 & 38,48 & 8,48 \\
\hline SGR & 1,14 & $-2,24$ & $-24,01$ & $-28,85$ & 4,36 & $-0,12$ & $-10,59$ & 18,59 & 70,76 & 22,22 \\
\hline SFGR & 5,11 & 2,43 & $-9,53$ & $-11,36$ & 4,68 & 2,70 & $-1,36$ & 10,18 & 30,93 & 30,93 \\
\hline
\end{tabular}

Eddig a FINel, most pedig áttérünk az EkoWIN pénzügyi szakértői rendszerrel végzett számítások eredményeinek közlésre.

A vizsgált 3 szálloda összminősítése a következő:

DH: a jó sáv harmadik negyedéből a legkedvezőtlenebb, alsó negyedébe kerül 2016-ban. D: a 2007. évi jó sáv második negyedéből visszaesik az elfogadható sáv második negyedébe (2010. év), majd 2016-ban visszakerül a 2007. évi jó sáv második negyedébe.

APH: hasonló, mint a D, de 2010-ben a problematikus sáv második negyedébe kerül (5. ábra).

Tehát egyértelműen kimutattuk egyrészt a 2008. évi globális válság hatását, másrészt a globális pénzügy-gazdasági válság nagyobb mértékben érintette a rangsor hátulsó részében levőket, vagyis a $\mathbf{D}$ és az $\mathbf{A P H}$ szállodát. A romló összminősítést a gyengülő jövedelemtermelőképesség befolyásolta, ezért tovább ezt elemezzük. 


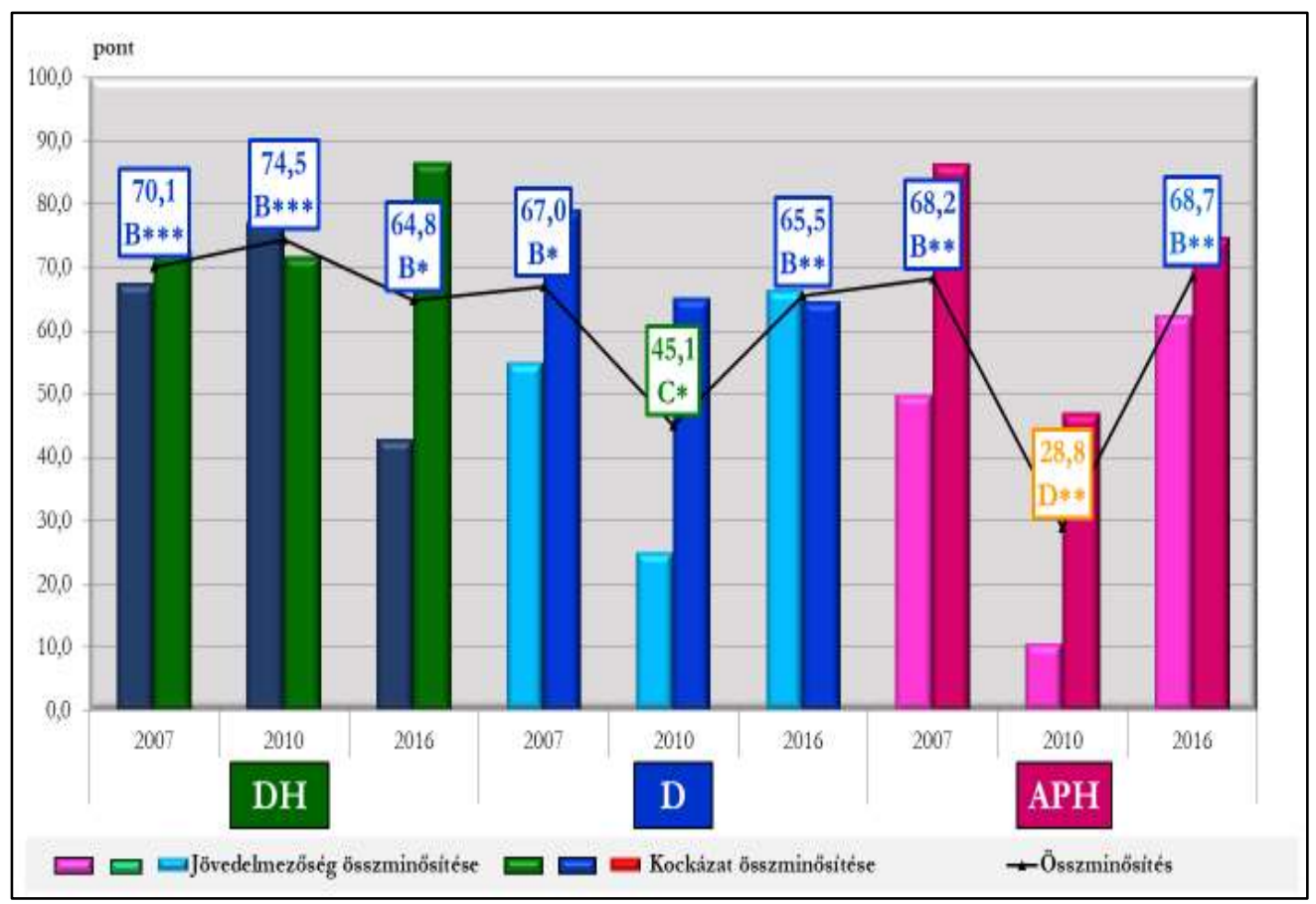

5. ábra. A 3 szálloda minősítése

Forrás: saját sz̨erkesztés az. EkoWIN szoftver alapján

A jövedelemtermelő képesség átfogó elemzése, illetve a vizsgálat komplexitása abban jelenik meg egyrészt, hogy a 3 cég teljesítményét három mutatószám csoporttal értékesítés, termelékenység és a pénzügyi realizáció oldaláról - is értékeljük, másrészt pedig minden mutatószám csoportban egyaránt léteznek bevétel/ráfordítás és eredmény/vagyon típusú mutatószámok. Az EkoWIN pénzügyi szakértői szoftverrel megkaptuk a jövedelmezőségi mix összetételét, s az eredményeket a 4. táblázat közli.

A vizsgált 3 szálloda jövedelemtermelő képességének minősítése a következő:

DH: a 2007. évi jó sáv második negyedéből a jó sáv legkedvezőbb, felső negyedébe (2010. év), majd 2016-ban az elfogadható sáv legkedvezőtlenebb első negyedébe esik.

D: a 2007. évi elfogadható sáv harmadik negyedéből a problematikus sáv legkedvezőtlenebb, alsó negyedébe (2010. év), majd 2016-ban a jó sáv második negyedébe esik. 
4. táblázat. A jövedelmezőségi mix értékeinek alakulása 3 üzleti évben (\%)

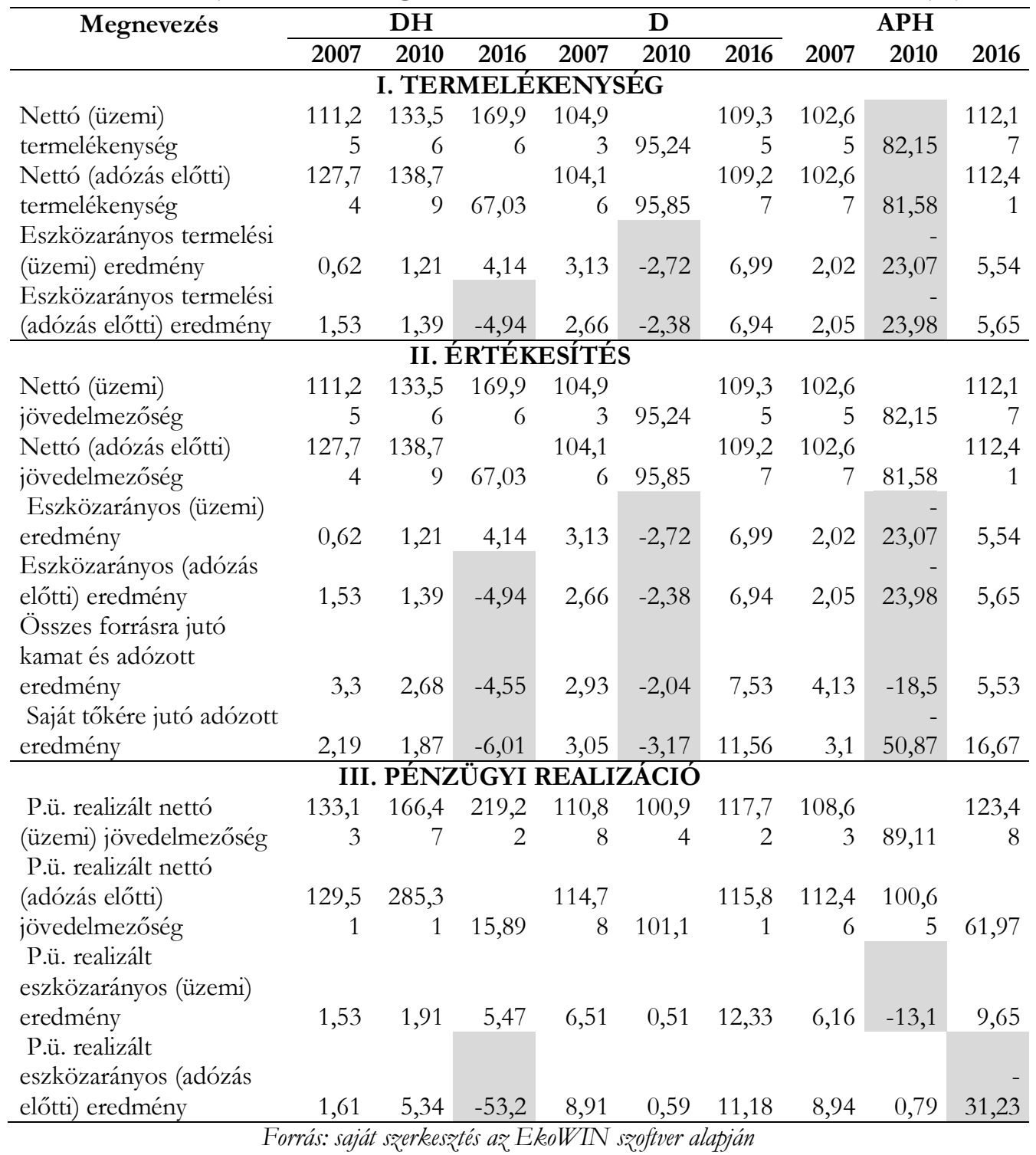

APH: a 2007. évi elfogadható sáv második negyedéből a kritikus sáv második negyedébe (2010. év), majd 2016-ban a jó sáv második negyedébe esik.

Tehát 2016-ra a rangsor hátulsó részében levő D és APH szálloda jövedelmezősége sokkal kedvezőbbé vált a DH szállodához képest, mivel termelékenysége és az értékesítés kiemelkedően kedvezően változott 2010-hez képest (6. ábra).

Meg kell jegyeznünk azt, hogy a 3 szálloda termelékenysége, értékesítése és a pénzügyi realizációja nem érte el a kiváló minősítést, sőt, az $\mathbf{A P H}$ szálloda esetében kritikus volt 
2010-ben, ellenben 2016-ra a legnagyobb fejlődést éppen az APH hozta, mivel, termelékenyége és értékesítése a jó sáv második negyedébe került.

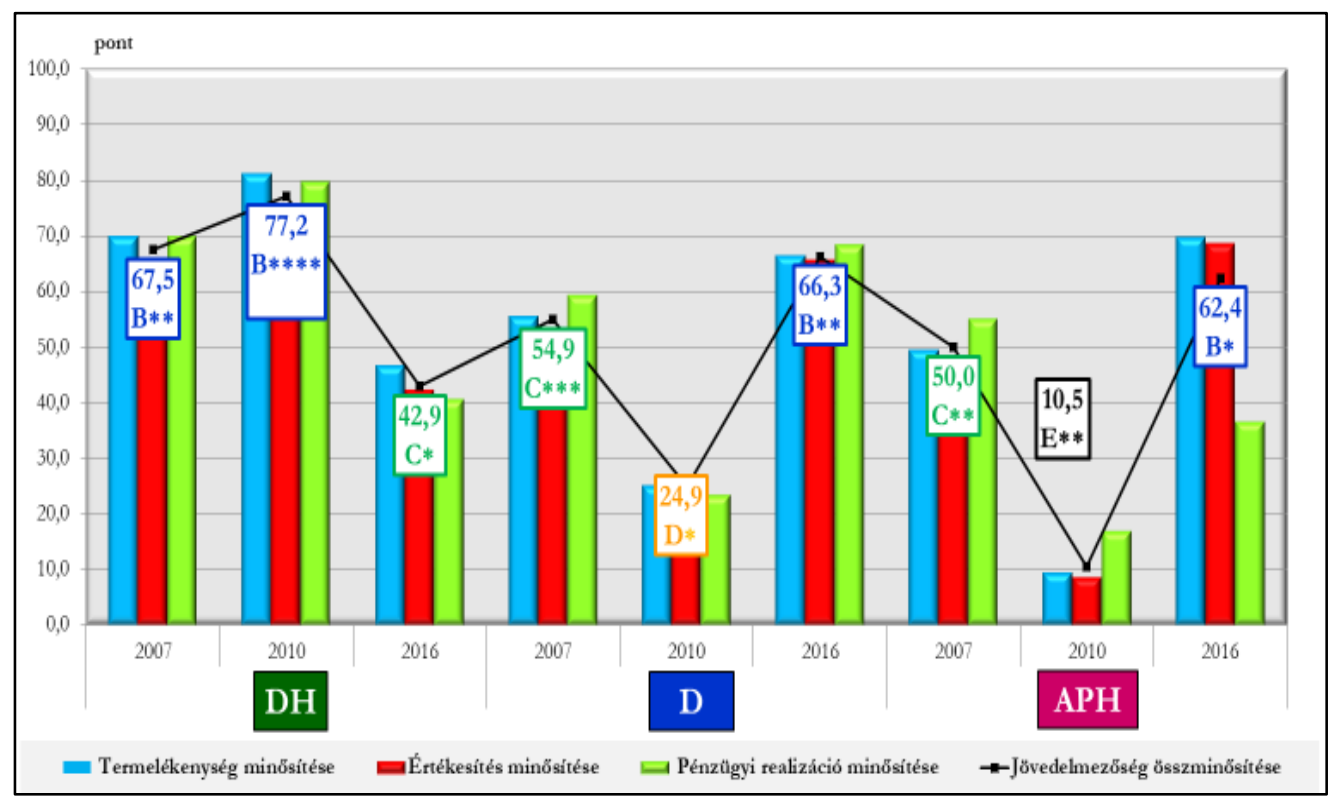

6. ábra. A 3 szálloda jövedelmezőségének minősítése

Forrás: saját szerkesztés az. EkoWIN szoftver alapján

Ha jövedelmezőségi mix értékelésével kapott sorolást (6. ábra) összehasonlítjuk a SaGR alakulásával (3. táblázat), akkor hasonló tendenciát látunk, ami szintén azt támasztja alá, hogy a jövedelmező gazdálkodás éltető ereje az értékesítés nettó árbevétele.

A pénzügyi elemzésen alapuló diagnóziskészítés nem nélkülözheti a nem szisztematikus (cég) kockázatok mértékére vonatkozó számítást és vizsgálatot Itt egy ún. kockázati mix értékelésérôl lesz szó, ami 5 mutatószám csoportból áll. A számítások eredményét a 5. táblázat tartalmazza és a 7. ábra szemlélteti.

A vizsgált 3 szálloda kockázatának minősítése a következő:

DH: a 2007. és a 2010. évi jó sáv harmadik negyedéből a kiváló sáv második negyedébe kerül.

D: a 2007. évi jó sáv legkedvezőbb, negyedik negyedéből a jó sáv második negyedébe (2010. év), majd 2016-ban a legkedvezőtlenebb, alsó negyedébe esik.

APH: a 2007. évi kiváló második negyedéből az elfogadható sáv legkedvezőtlenebb, alsó negyedébe (2010. év), majd 2016-ban a jó sáv harmadik negyedébe esik (7. ábra). 
5. táblázat. A kockázati mix értékeinek alakulása 3 üzleti évben

\begin{tabular}{|c|c|c|c|c|c|c|c|c|c|}
\hline \multirow{2}{*}{ Megnevezés } & \multicolumn{3}{|c|}{$\mathbf{D H}$} & \multicolumn{3}{|c|}{$\mathbf{D}$} & \multicolumn{3}{|c|}{$\mathbf{A P H}$} \\
\hline & 2007 & 2010 & 2016 & 2007 & 2010 & 2016 & 2007 & 2010 & 2016 \\
\hline \multicolumn{10}{|c|}{ I. TÖKESZERKEZET (\%) } \\
\hline Tőkeellátottság & 69,55 & 74,44 & 82,71 & 77,97 & 76,17 & 60,41 & 59,72 & 52,98 & 31,86 \\
\hline $\begin{array}{l}\text { Fedezeti tőke } \\
\text { dinamikája }\end{array}$ & 1,52 & 1,40 & $-17,23$ & 0,00 & $-2,38$ & $-6,59$ & 0,65 & 4,38 & 15,21 \\
\hline $\begin{array}{l}\text { Tartós forrásokon } \\
\text { b. tőkeellátottság }\end{array}$ & 76,07 & 80,71 & 85,31 & 91,01 & 84,73 & 78,78 & 77,17 & 100,0 & 36,68 \\
\hline $\begin{array}{l}\text { Befektetett eszk. } \\
\text { tőkefedezete }\end{array}$ & 74,41 & 78,18 & 95,77 & 88,06 & 81,71 & 69,04 & 82,17 & 66,56 & 85,57 \\
\hline $\begin{array}{l}\text { Hosszú lej. kötel. } \\
\text { eszközfedezete }\end{array}$ & $\begin{array}{r}427,2 \\
2\end{array}$ & $\begin{array}{r}535,2 \\
2\end{array}$ & $\begin{array}{r}606,4 \\
6\end{array}$ & $\begin{array}{r}1149 \\
67\end{array}$ & $\begin{array}{r}679,1 \\
8\end{array}$ & $\begin{array}{r}537,7 \\
8\end{array}$ & $\begin{array}{r}411,2 \\
9\end{array}$ & - & 67,70 \\
\hline \multicolumn{10}{|c|}{ II. ESZKÖZFINANSZÍROZÁS (\%) } \\
\hline $\begin{array}{l}\text { Keresztbe fin. } \\
\text { összes forrás \%- } \\
\text { ban } \\
\text { Keresztbe fin. a } \\
\text { saját tőke \%-ban }\end{array}$ & 2,04 & 2,99 & 0,00 & 2,87 & 3,32 & 10,82 & 0,00 & 33,41 & 0,00 \\
\hline \multicolumn{10}{|c|}{ III. STATIKUS LIKVIDITÁS (\%) } \\
\hline $\begin{array}{l}\text { Azonnali likviditási } \\
\text { mutató }\end{array}$ & 6,27 & 23,78 & 0,86 & 1,79 & 0,76 & 1,99 & 1,81 & 1,25 & 9,36 \\
\hline $\begin{array}{l}\text { Gyors likviditási } \\
\text { mutató }\end{array}$ & 9,33 & 24,48 & 12,62 & 1,70 & 1,03 & 1,12 & 3,72 & 1,49 & 12,62 \\
\hline $\begin{array}{l}\text { Általános } \\
\text { likviditási mutató }\end{array}$ & 0,82 & 0,65 & 5,26 & 0,87 & 0,80 & 0,67 & 1,52 & 0,33 & 8,75 \\
\hline $\begin{array}{l}\text { Teljes likviditási } \\
\text { mutató }\end{array}$ & 0,76 & 0,62 & 4,48 & 0,84 & 0,71 & 0,57 & 1,28 & 0,38 & 5,35 \\
\hline \multicolumn{10}{|c|}{ IV. DINAMIKUS LIKVIDITÁS (\%) } \\
\hline $\begin{array}{l}\text { Összes kötel. cash } \\
\text { flow fedezete } \\
\text { Rövid }\end{array}$ & 7,89 & 8,33 & 0,00 & 37,67 & 6,05 & 41,52 & 21,69 & 0,00 & 13,56 \\
\hline $\begin{array}{l}\text { kötel.cash flow } \\
\text { fedezete }\end{array}$ & 30,42 & 28,71 & 0,00 & 70,50 & 24,06 & $\begin{array}{r}102,8 \\
9\end{array}$ & 51,16 & 0,00 & 229,47 \\
\hline $\begin{array}{l}\text { Tartós forrás hiány } \\
\text { várható futamideje } \\
\text { (év) }\end{array}$ & 0,90 & 1,40 & 0,00 & 0,50 & 3,00 & 1,00 & 0,00 & 100,0 & 0,00 \\
\hline \multicolumn{10}{|c|}{ V. MÚKOÖDÉSI ÉS FINANSZÍROZÁSI DINAMIKA (nap) } \\
\hline $\begin{array}{l}\text { Szállítók } \\
\text { futamideje }\end{array}$ & 39,76 & 8,27 & 39,64 & 25,56 & 25,41 & 42,45 & 18,21 & 21,06 & 33,21 \\
\hline $\begin{array}{l}\text { Vevők futamideje } \\
\text { Készletek }\end{array}$ & 0,20 & 0,03 & 0,05 & 14,51 & 9,15 & 9,65 & 18,11 & 14,45 & 13,23 \\
\hline $\begin{array}{l}\text { futamideje } \\
\text { Vevők és készletek } \\
\text { szállítókkal }\end{array}$ & 0,44 & 0,27 & 0,01 & 2,81 & 2,63 & 2,45 & 2,47 & 2,38 & 2,10 \\
\hline finanszírozott & 2111, & 979,2 & 15420 & & 123,9 & 181,9 & & & \\
\hline részaránya & 83 & 2 & ,9 & 79,20 & 8 & 7 & 55,77 & 91,50 & 132,31 \\
\hline
\end{tabular}


Tehát a rangsor hátulsó részében levő D és APH szálloda kockázata magasabb lett 2016ban, mint a globális pénzügy-gazdasági válság előtt, mialatt a rangsorban a kedvezőbb helyen álló DH szálloda kockázata úgy csökkent, hogy a kiváló sávban végzett. Mindhárom esetben az operatív üzletmenet (működési finanszírozási dinamika) kiváló volt, de a fizetőképességgel és -készséggel 2007-ben és 2010-ben problémák voltak, miközben kizárólag 2016-ban az APH tőkeszerkezete, s így finanszírozási kockázata emelkedett, míg a D eszközfinanszírozási kockázata romlott.

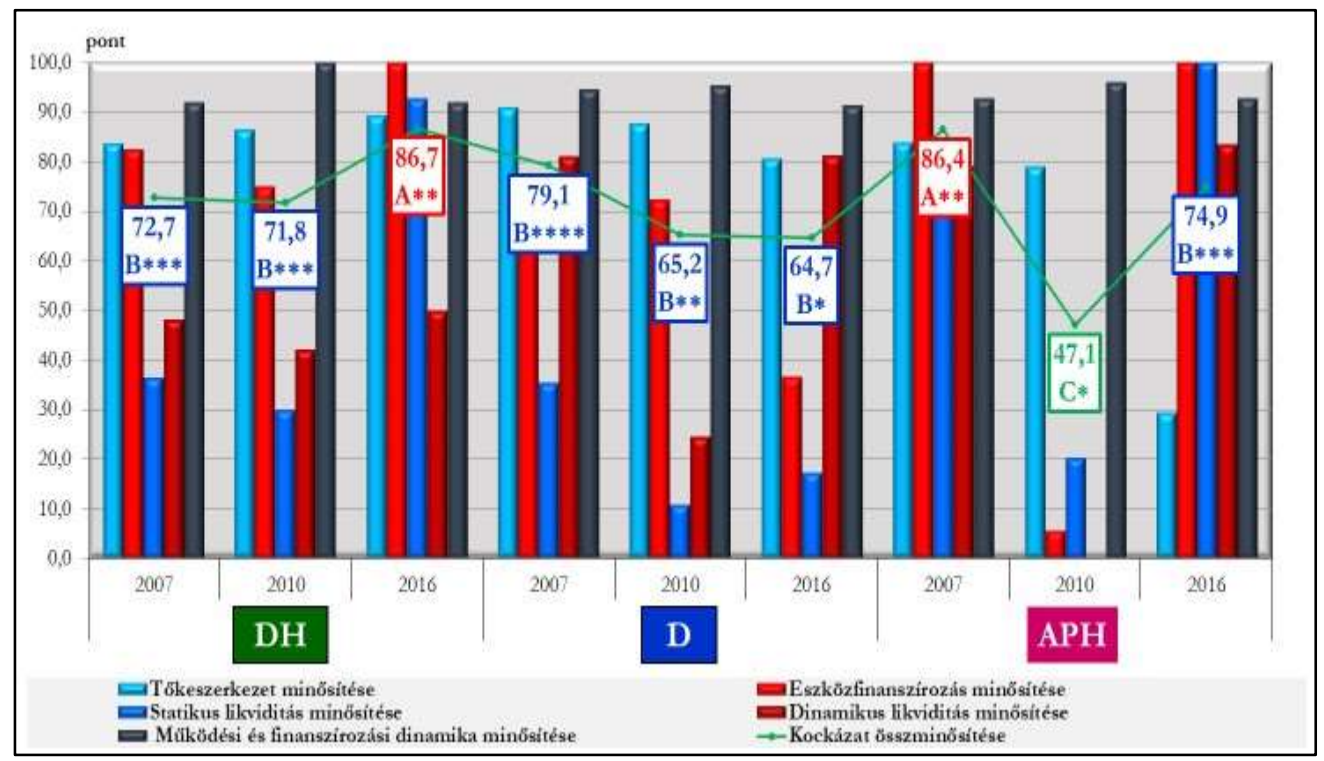

7. ábra. A 3 szálloda kockázatának minősítése

Forrás: saját szerkesztés az. EkoWIN szoftver alapján

A 8. ábra abszcissza tengelye a jövedelmezőség, az ordináta tengelye a biztonság (azaz kockázatviselő képesség) minősítési pontszáma szerint van skálázva. A vastagon keretezett területek a különböző vállalati kilátásokat kifejező zónák, melyeket a jobbra látható jelmagyarázatok azonosítanak. A piros pont az adott szálloda pillanatnyi helyzetét mutatja, melyet piros szaggatott vonalak vetítenek a tengelyekre. A piros ponton átmenő ferde, fekete szaggatott vonal az állandó pontszámú pénzügyi összminősítés egyenese. A 8. ábra szemlélteti 3 szálloda piaci pozíciójátnak alakulását a 2007 és 2016 közötti beszámolási időszakra. A 3 szálloda közül csak a D pozíciója javult 2016 végére, de mindhárom szálloda a 'sikes' zónájába került. Amíg a D és az APH szálloda a 'feszültség', majd a 'remény'zónából jutott a 'siker' zónába, addig a $\mathbf{D H}$ szálloda 'mozgása', helyezése kisebb intervallumban történt, miközben 2014-ben a legkedvezőbb pozíciót is elérte. 


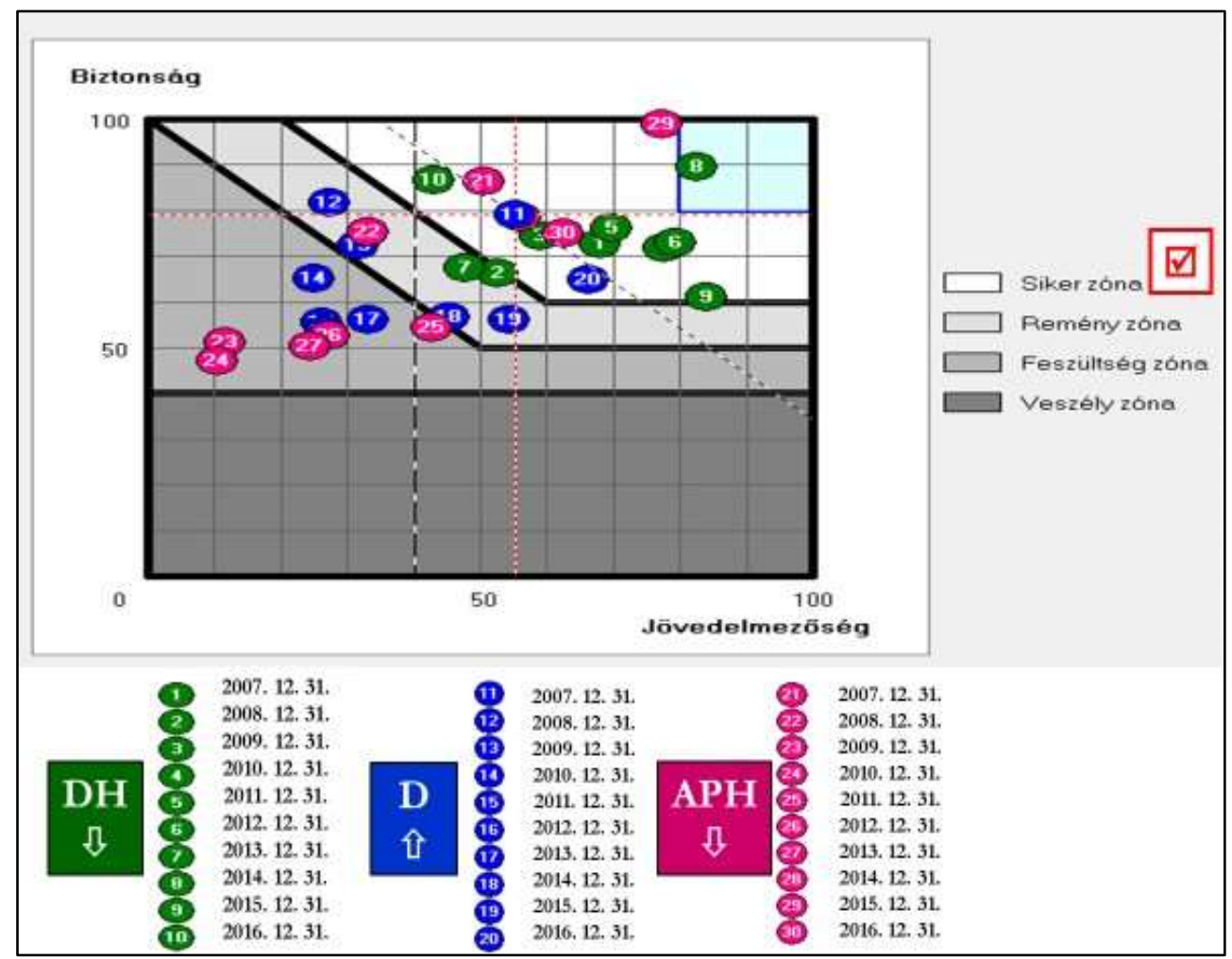

8. ábra. A szálloda pénzügyi pozíciójának változása 2007 és 2016 között

Forrás: EkoWIN szoftverrel készített output tábla

\section{ÖSSZEGZÉS, KÖVETKEZTETÉSEK ÉS JAVASLATOK}

A vizsgálatunk két kérdésre kereste választ:

1. A vizsgált cég vagy ágazat vajon jövedelmező, miközben fizetőképes, nem eladósodott, perspektivikus a működése, valamint hatékony eszköz- és vagyongazdálkodást folytat?

2. Hogyan változott a pénzügyi pozíció térkép a jövedelmezőségi és kockázati mix függvényében?

Az 1. kérdésre határozott 'igen' választ nem tudunk adni még akkor sem, ha a vizsgálatunk utolsó, 2016. üzleti évében javuló értékeket kaptunk éppen a rangsor hátulsó részében szerzett helyezéseken levő cég esetében (2-5. táblázat és 5-7. ábra).

A 2. kérdésre a válaszunk hasonló, mint az 1. kérdésre adott válaszunk. Bár mindhárom esetben nagyon sikeres 'mozgást' látunk, mégis a 'legnagyobb és kedvező ugrást' a rangsor hátulsó részében szerzett helyezéseken levő cégek tették (8.ábra).

Olyan pénzügyi támpontok közlése volt a célunk, amelyek segítik a turizmus ágazatban működő üzleti egységeket pénzügyileg stabil alapra helyezni és a növekedési pályán tartani. A következőkre kellene törekedni: Ne legyen visszaesés az üzleti forgalomban, a jövedelmezőségben, a fizetőképességben és az eszközhatékonyságban, így a turizmus szektor a növekedési pályán képes maradni. Bízni tudunk abban, hogy átgondolt 
racionalizálással és az elavult, korszerűtlen tevékenységek piaci szelektálódásával valóban FORDULAT történt. Amennyiben az eredménykimutatásból számított SaGR növekedési ráták meghaladják az IGR, SGR és SFGR növekedési ráta számított értékeit, úgy az adott gazdasági egység nem tud eleget tenni fizetési kötelezettségeinek, s a finanszírozási kapacitása felborul, így tényleges lépéseket kell tenni gazdálkodása javítása érdekében (a turnaround menedzselés eszközeivel). A vizsgált szállodák múködési költséghányadát tevékenység- és folyamatracionalizálással mérsékelni lehet; magas(abb) IGR és SFGR növekedési rátát érhetnének el a belső finanszírozási erő menedzselésével; a tőkeszerkezet fenntartását célzó és az azt meghaladó, erőltetett árbevétel növekedését szolgálnia kellene az eszközökkel történő hatékony gazdálkodás, amelynek kontrollállását segíti a FINel és az EkoWIN elemzési moduljai.

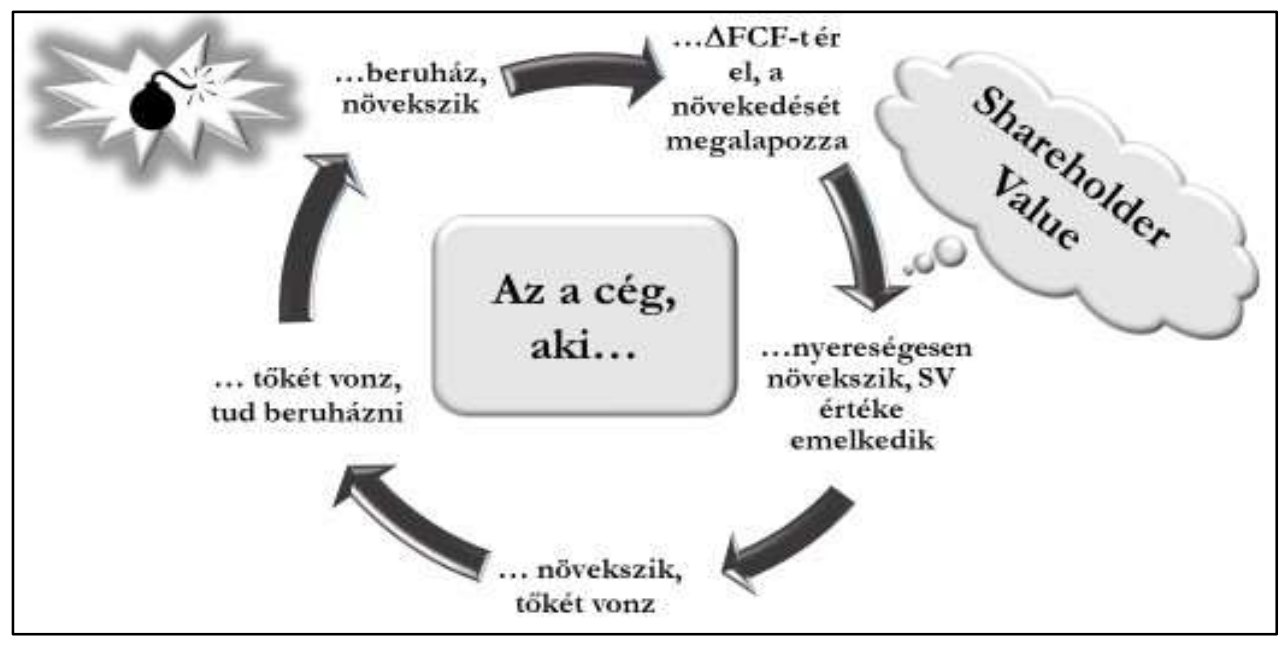

9. ábra. Az értékteremtési kör

Forrás: saját szerkesztés

Javasoljuk az értékesítési árbevételből levezetett nyereségre vonatkozó növekedési cél megfogalmazását, amely a tulajdonosi érték (SV = Shareholder Value) növelése érdekében történik. A gyújtópont a hatékony beruházás realizálása. Azt azonban itt hangsúlyoznunk kell, hogy az SV-koncepció keretében a növekedés nem cél, hanem a stratégiai tervezési folyamat következménye, ami az SV maximalizálására irányul. A 9. ábra közli azt az értékteremtési kört, amely hozzájárul a növekményes SV létrejöttéhez.

A Kisfaludy Program első ütemének köszönhetően több mint 700 helyen találkozhatunk megújult panziókkal, szálláshelyekkel a következő években a vidéki Magyarországon. A Kisfaludy Program minden idők legnagyobb hazai forrásból megvalósuló szálláshelyfejlesztési programja, amelynek köszönhetően 300 milliárd forintos értékben valósulnak meg beruházások a vidéki Magyarország szálláshelyein, ehhez pedig 150 milliárd forint vissza nem térítendő támogatást nyújt Magyarország Kormánya. a Kisfaludy Programmal azt szeretnénk elérni, hogy minden magyar panzió egy kategóriát 
léphessen előre. Mindez által célunk, hogy a vidéki panziók és szállodák versenyképesebbek, nyereségesek és hosszú távon fenntarthatók legyenek, a beruházások által pedig a magyar turizmus mutatószámai tovább növekedjenek (origo.hu, 2019). Tehát a magyar turizmus kitörési pontja: a minőség emelése az állami pénzügyi támogatással megvalósított beruházások összekapcsolásával a versenyképesség, az eredményesség és a fenntarthatóság érdekében.

A közölt esetek és ágazati értékek vizsgálatával igazoltuk azt, hogy a pénzügyi diagnóziskészítés keretében történt a múködés gyenge és erős pontjainak feltárása, elemzése, amellyel eljutunk a közbenső okok felismerésén keresztül a végső okhoz, amelynek megszüntetésére a pénzügyi vezetés operatív és/vagy stratégiai jellegú intézkedéseket hozhat. A pénzügyi elemző a fejlődő válság látens fázisát óhajtja megtalálni. A jelzések mutatják a tüneteket és segítenek a válság típusát azonosítani, a felismert okokra/problémákra operatív és stratégiai technikákat dolgozunk ki.

A 2-5. táblázatok szürke háttérrel jelzett értékei a pénzügyi tüneteket, a "gyenge" jelzéseket mutatták, amelyek az üzleti egység funkcionális területéről származnak. Itt kiemeljük a makrogazdasági indikátorok és az ágazati konjunktúra alakulásának figyelmeztetéseit is, amelyből a vizsgált szállodák sem vonhatták ki magukat. A preventív turnaround technikával a szolgáltatás igények és a profil stratégiai elemzésével, az ügyfelek/vendégek magatartás vizsgálatával és előre jelzések készítésével a hanyatló tendenciát elkerülhetik, de még a reorganizációs turnaround keretében is projektek és a tevékenységek ésszerűsítésével, az értékteremtő és -romboló folyamatok ideje korán történő felülvizsgálatával a végzetes végkifejlet nem történik meg. Természtesen mindezt fejlődő válság esetében tudjuk megtenni.

Az alábbi 4 kérdés megválaszolásával a következő nem szisztematikus kockázati tényezőket vizsgáltuk:

1. Vajon az árbevétel növekedés jövedelmező gazdálkodással és finanszírozási biztonsággal jár? - Értékesítési kockázat. Pénzügyi módszer: IGR, SGR és SFGR növekedési ráták számítása a $\mathrm{SaGR}$ ismeretében.

2. Fizetőkészek és -képesek vagyunk? - Likviditási és csődveszély kockázat. Pénzügyi módszer: statikus és dinamikus likviditás számítása, fizetőképességi prognózis készítése, RL likviditási helyzetfeltárás.

3. Mekkora az adósság? Milyen az eszközfinanszírozás? - Befektetési és finanszírozási kockázat. Pénzügyi módszer: tőkestruktúra és tulajdonosi arány, eszközfinanszírozás, „aranyszabályok” számítása.

4. Zökkenőmentes és hatékony az üzletmenet? - Üzleti kockázat. Pénzügyi módszer: működési és finanszírozási dinamika, átfogó forgótőke gazdálkodás vizsgálata, profit- és cash alapú fedezeti analízis, érzékenységi vizsgálat, ZVEI szerkezet-analízis, RL jövedelmezőségi helyzetfeltárás.

A vizsgálat utolsó évében kedvező képet kaptunk a top cégek SaGR, a tőkeszerkezet, az eszközök és azokat finanszírozó források alakulásáról, a forgótőke gazdálkodás mértékéről, amely az értékesítési, befektetési és finanszírozási kockázat, valamint az üzleti 
kockázat kedvező szintjét is jelentik, s növelik a turizmus ágazat befektetői vonzó erejét (7. ábra). Az IGR, SGR és SFGR növekedési ráták alakulása azt jelzi, hogy pofitvisszatartásból és a mérleg szerinti tőkeszerkezet fenntartásával 2014-től még nagyobb árbevételt lehetett volna elérni a rangsorban hátrább álló $\mathbf{D}$ és $\mathbf{A P H}$ esetében (3. táblázat). 2016-ban az eszközfinanszírozás és a forgótőke menedzselése (7.ábra) kitűnő minősítés mellett történt, ami mérsékelt befektetési és finanszírozási, valamint üzleti kockázatra utal, de a likviditás (7. ábra) minősítése miatt a likviditás menedzselése külön figyelmet igényel. A fizetőkészség és -képesség erősítése érdekében a megfelelő partnerségek kialakításával a belső erőforrásokat lehet mozgósítani. Az IKT-eszközök, az digitalizáció és a robotizáció segíthetik az üzleti egységek innovatívabb, hatékonyabb, termelékenyebb müködését.

A vizsgálat eredményei segíthetik a pénzügyi vezetők

- tervezési munkáját a növekedési ráták és a (statikus és dinamikus) likviditás számításával, a múködési cash ciklus pénzlekötési és hitelnyújtási idejének kalkulálásával;

- menedzselési munkáját különösen az operatív üzletmenet területén;

- monitoring és kontrolling munkáját, itt különösen az IGR és SGR növekedési ráták vizsgálatát SaGR ismeretében, a hozamtermelés és az eszközfinanszírozás megfelelőségében, valamint az időpontra és -tartamra vonatkozó likviditás felügyeletében.

Mindenképpen pénzügyi szemlélet- és módszertani bővítést igényel egyrészt a robotizáció, a digitalizáció és az automatizáció, másrészt igényli az agilis vezetői szemlélet is, harmadrészt a mindezt úgy kell bevinni és beépíteni a céges praktikumba, hogy az előre látó, a változások elé menő, de a gazdálkodás óvó-védő szemléletet is kifejlesszük.

A vállalati pénzügyi praxis és tanácsadás igényli a pénzügyi módszertan árnyalt kezelését, vagyis a cégek profilja, mérete, piaci viszonyai, versenytársai „bemérése” függvényében kell kialakítani és működtetni pénzügyi tervezési, elemzési és ellenőrzési eszköztárát az életszakasz azonosítása után. Eltérő menedzselési eszközt és módszertant igényel egy induló cég, s itt nem mindegy az, hogy imitáló vagy innováló vállalkozói tevékenységet folytat, ha növekszik kezdetben, aztán érett szakaszában van, majd pedig hanyatlik. A best practic tanulságait hatékonyan feldolgozni és beépíteni a megfelelő életszakaszba illesztve lehet és érdemes. Így azonosítani tudjuk pénzügyi diagnózis készítéséhez a növekedési indikátorokat (2-3. táblázat), a nem szisztematikus kockázatokat (5. táblázat és 7. ábra) és a fejlődő, látens válság jelzéseit és okait (KATITS, 2017b). A szisztematikus és kritikus monitoring és kontrolling rendszer múködtetéséhez igazítva (lenne) érdemes kialakítani korai figyelmeztető, felismerő, felderítő és előrejelző rendszert. A stabil vállalati gazdálkodás támogatója: az életszakaszoknak megfelelő és a cég profiljára illesztett kontrolling- és korai előrejelző rendszer kiépítése, valamint tanuláson alapuló működtetése.

A kifejező növekedési indikátorok számolása különösen fontos nemcsak pénzügyi, hanem stratégiai és marketing, de a versenyelemzés és „bencmarking” területek megítéléséhez is (2. tábláat és 8. ábra). A lényeges értékteremtők (az árbevétel növekedési 
rátája, a múködési jövedelmezőség, az eszközhatékonyság inverze az eszközintenzitási ráta) mint növekedési indikátorok, hektikusan változtak 2007 és 2016 között. Ezek, mint figyelmeztető jelek a lehetségesen helytelen út elkerülését, valamint a turizmus „benchmarks” azonosítását szolgálják.

A fenntartható fejlődés mind hazai, mind nemzetközi téren is egyre nagyobb szerepet kap. Állami feladat, többek között, ezt tudatosan fejleszteni és az alapfeltételeket megteremteni. A turizmus fejlesztése szempontjából fontos kötelezettségei vannak a magánszektornak, a lakosságnak és a szakmai szervezeteknek is. Ha mindezt sikerül megvalósítani, akkor a turizmus lehet a legversenyképesebb ágazatunk és a nemzetgazdaságunk legmeghatározóbb élénkülő egysége.

\section{FELHASZNÁLT IRODALOM}

Altman, Edward I. (1988): The Prediction of Corporate Bankruptcy: A Discriminant Analysis. New York, Garland, 149 p. ISBN: 0824061136, https://doi.org/10.2307/2325319

BABCOCK, Guilford C. (1970): The Concept of Sustainable Growth. Financial Analysts Journal, Vol. 26, No. 3 (May-Jun), pp. 108-114., https://doi.org/10.2469/faj.v26.n3.108

Bodie, Zvie - Cleeton, David L. - MerTon, Robert C. (2011): A pénzügyek közgazdaságtana. Budapest, Osiris Kiadó, 627 p. ISBN: 9789632761824

BREALEy, Richard A. - MYers, Stewart C. (1999): Modern vállalati pénzügyek. Budapest, Panem Kiadó, 1. kötet, 535 p. ISBN: 963545225

BuCHNER, R. (1985): Finanzwirtschaftliche Statistik und Kennzahlenrechnung. München, Vahlen Verlag, 430 p. ISBN: 9783800610822

CHAndra, Prassana (2011): Financial Management. New Delhi, Tata McGraw Hill, 1062 p. ISBN: 9780071078405

Churchill, Neil C. - Muldins, John W. (2001): How Fast Can Your Company Afford to Grow? Harvard Business Review, 79(5), pp. 135-166.

Damodaran, Aswath (2006): A befektetések értékelése. Budapest, Panem Kiadó, 1065 p. ISBN: 9879635454556

DAvis, Charles E. - DAvis, Elizabeth B. (2011): Managerial Accounting. Wiley, Hoboken, 752 p. ISBN: 9780471699606

FABOZZI, Frank J. - MARKOWITZ, Harry M. (2011): Equity Valuation and Portfolio Management. New Jersey, John Wiley \& Sons, 544 p. ISBN: 9780470929919

FAZAKAS Gergely (2001): Vállalati pénzügyek. Tatabánya, TRI-MESTER, 179 p. ISBN: 9630060604

GEBHARDT, Günther (1980): Insolvenæprognosen aus aktienrechtlichen Jahresabschlüssen. Wiesbaden, Gabler Verlag, 338 p. ISBN: 9783409160919, https://doi.org/10.1007/978-3-322$\underline{87942-4}$

Higgins, Robert C. (1981): Sustainable Growth under Inflation. Financial Management, Vol. 10, No. 4 (Autumn), pp. 36-40., https://doi.org/10.2307/3665217 
KATITS Etelka - Pogátsa Zoltán - Zsupanekné Palányi Ildikó (2018): A nemzetgazdasági konjunktúraciklusok és vállalati életciklusok - Modellek és bírálatok (bővített változat). Budapest, Akadémiai Kiadó, 371 p. ISBN: 9789634541547

KATITS Etelka (2010): A vállalati válság pénzügyi menedzselése (teória és praxis). Budapest, Saldo Kiadó, 507 p. ISBN: 9789636383466

KATITS Etelka (2017a): A vállalati (életciklus) pénzügyek - Fogalomtár és alapvető módszertan. Sopron, Soproni Egyetem Kiadó, 348 p. ISBN: 9789633342534

KATITS Etelka (2017b): Haladó vállalati (életciklus) pénzügyek - Pénzügyek változ(tat)ások idején. Sopron, Soproni Egyetem Kiadó, 486 p. ISBN: 9789633343036

ksh.hu, 2018: http://www.ksh.hu/docs/hun/xftp/gyor/jel/jel1803.pdf Letöltés ideje: 2019. 06. 15.

KUCSÉBER László Zoltán (2015): Hogyan befolyásolják a vállalatfelvásárlások a felvásárló cégek jövedelemtermelő képességét? Tér-Gazdaság-Ember, 3:3 pp. 55-67.

KUCSÉBER László Zoltán (2016): A hazai felvásárlás előtt és után: fókuszban a forgótőkemenedzselés. Hitelintézeti Szemle/Financial and Economic Review, 15:1 pp. 70-90.

Marks, Kenneth H. - Robbins, Larry E. - Fernandez, Gonzalo - FunKHoser, John P. Williams, D. L. (2009): Handbook of Financing Growth: Strategies and Capital Structure, and M\&A Transactions. Hoboken, John Wiley \& Sons, 672 p. ISBN: 978-0-470-39015-3

mtu.gov.hu, 2018: https://mtu.gov.hu/cikkek/a-turizmus-eredmenyei-magyarorszagon Letöltés ideje: 2019. 06. 15.

netjogtar.hu, 2019: https://net.jogtar.hu/jogszabaly?docid=A0000100.TVLetöltés ideje: 2019.

06. 15 .

origo.hu, 2019: https://www.origo.hu/itthon/20190103-guller-zoltan-evertekelo-interju-

magyar-turisztikai-ugynokseg.html Letöltés ideje: 2019. 04. 20.

Parrino, Robert - Moles, Peter - Kidwell, David S. (2016): Fundamentals of Corporate Finance. Hoboken, John Wiley \& Sons, 832 p. ISBN: 9781118959268

SinkOVICS Alfréd (2012): Vállalati pénzügyi tervezés. Budapest, Complex Kiadó, epub. ISBN: 9789632952048

TAKÁCS András (2009): Vállalatértékelés magyar számviteli környezetben. Budapest, Perfekt Kiadó, 200 p. ISBN 9789633947678

Van Horne, James C. - Waczhowicz, John M. (2008): Fundamentals of Financial Management. Harlow, Pearson Education, 719 p. ISBN: 9780273713630 
${ }^{18}$ 这 57
BGE 